DEPARTMENT OF COMMERCE

BUREAU OF STANDARDS

George K. Burgess, Director

TECHNOLOGIC PAPERS OF THE BUREAU OF STANDARDS, No. 248

[Part of Vol. 18]

\title{
EXPOSURE TESTS \\ ON COLORLESS WATERPROOFING MATERIALS
}

\author{
BY \\ D. W. KESSLER, Associate Engineer Physicist \\ Bureau of Standards
}

January 7, 1924

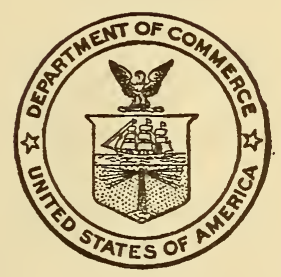

PRICE, 15 CENTS

\$1.25 PER VOLUME ON SUBSCRIPTION

Sold only by the Superintendent of Documents, Government Printing Office Washington, D. C.

WASHINGTON

GOVERNMENT PRINTING OFFICE 



\title{
EXPOSURE TESTS ON COLORLESS WATERPROOFING MATERIALS.
}

\author{
By D. W. Kessler.
}

ABSTRACT.

This paper describes the nature of several colorless waterproofing materials, and physical tests on the various treatments to determine their relative effectiveness, durability, etc. This type of materials is applied to the surface of such porous materials as stone, brick, and concrete in order to render them impervious to moisture without materially changing the natural appearance of the surface. A successful treatment of this kind serves certain useful purposes, viz: To seal up the pores of masonry walls which allow dampness to penetrate from the exterior face to the interior of the building; to act as a preservative on old buildings, monuments, etc., which are disintegrating due to frost action; to retard the absorption of soot, dust, and stains which mar the appearance of structures.

The greater number of the materials experimented with consisted of paraffin, china wood oil, aluminum soap, and resinous materials dissolved in light mineral solvents. These are applied to the surface of the stone like paint. The dissolved matter is carried into the pores of the stone and as the solvents evaporate a considerable portion of the solid matter remains in the stone, which tends to fill or seal the pores.

The tests upon which this report is based were made on specimens of limestone and sandstone that were treated on all sides with the waterproofing materials. These specimens were exposed to the weather and at intervals of a few weeks they were brought into the laboratory and tested for absorption. Some of the treatments proved to be almost worthless from the beginning, others deteriorated rapidly after a few months' exposure while a few have shown practically no deterioration during two years' exposure.

\section{CONTENTS.}

Page.

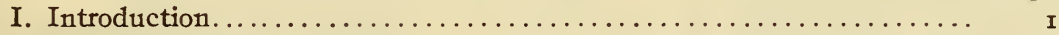

II. Description of tests. . . . . . .

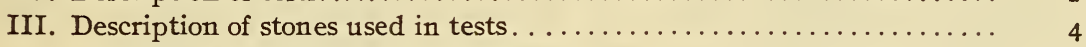

IV. Description of waterproofing materials. . . . . . . . . . . . . 6

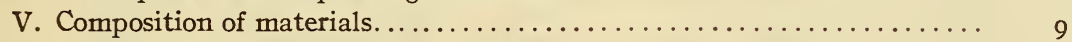

VI. Results of tests on the long-period exposures................ I5

VII. Appearance of treatments on limestone . . . . . . . . . . . . 24

VIII. Results of tests on various textures of sandstone............. 25

IX. Appearance of the waterproofing treatments on the sandstones ...... 29

$\mathrm{X}$. Tests for rate of absorption on treated specimens ............. 30

XI. Tests for rate of drying on treated specimens. . . . . . . . . .

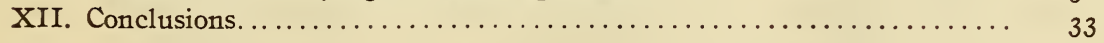

\section{INTRODUCTION.}

In the latter part of the year I920 the National Park Service requested this bureau to recommend a means of preserving some inscriptions on an old sandstone monument in E1 Morro National 
Park, N. Mex. Since there was only a small amount of data available on the subject of stone preservatives, especially on the period of their effectiveness, some tests were started on a sample of the stone in question. Due to the general demand for information on this subject the work was expanded to include a considerable number of proprietary materials, and a few other nonproprietary processes. These materials consist principally of thin liquids which carry solid matter in solution for the purpose of sealing up the pores of the stone.

The tests herein described have a fourfold object, viz: First, to compare the effectiveness of the various materials or methods in preventing absorption; second, to determine their lasting qualities or period of effectiveness; third, to determine the relative effectiveness of the materials on stones of various textures; fourth, to determine their effect on the appearance of the stone.

The entire group of specimens and the manner of exposure on the roof of our Industrial Building is shown in Figure I. The specimens number approximately 400 and consist of limestones from Io quarries in Indiana, I sandstone from New Mexico, I sandstone from Mississippi, and 3 sandstones from Ohio. The total number of absorption tests on all of the specimens amount to more than 3,000 .

A preliminary report was issued on some of these tests at the end of the six months exposure period. The present report is a continuation of that work over a period of two years, together with a considerable number of additional tests which were started at a later date.

Acknowledgment is made to E. H. Berger, of this bureau, for making chemical analyses on the waterproofing compounds, and for many valuable suggestions in classifying the materials.

\section{DESCRIPTION OF TESTS.}

For determining the relative effectiveness of the materials and also their durability, specimens of stone were prepared of a size and shape that could be conveniently tested for absorption. These were cylindrical in form, 2 inches in diameter and about $2 \mathrm{~T} / 2$ inches high. These specimens were thoroughly dried before they were treated. A minor group of three of these specimens was treated with each waterproofing material. The treatments were applied in accordance with the directions furnished by the producers, which in most cases consisted of two coats of the materials applied with a brush at 24 -hour intervals. A major 


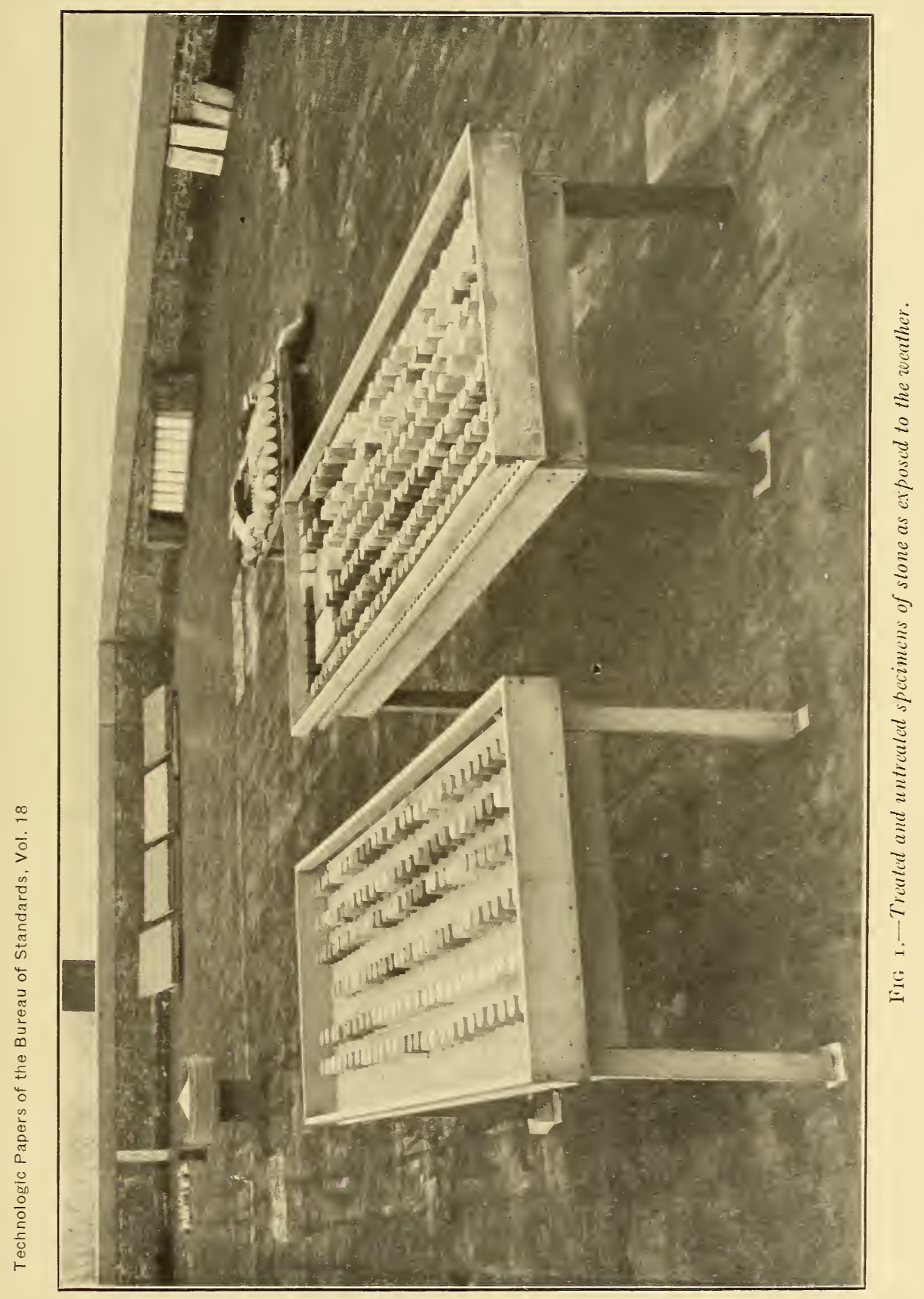



group, consisting of about 24 specimens treated with eight waterproofing materials, was put out on the roof upon the same date. After the end of one month or, in some cases a longer period, a major group was taken into the laboratory for absorption tests. Each specimen was weighed and then completely immersed in water for 30 minutes. At the end of this time they were surface dried with a towel and weighed again to determine how much water was absorbed.

The number of specimens (24) in a major group was determined by the number of weighings that could be made in 30 minutes. The specimens were weighed to $\mathrm{I} \mathrm{cg}$ and placed in the water in consecutive order, so by the time the dry weight of the twentyfourth specimen was obtained, the first one of the group had been in water nearly 30 minutes. The results of the absorption tests are shown graphically for the whole period of exposure by curves in Figures 2, 3, 4, 5, 6, 7, 10, and I I. Instead of plotting a curve for each specimen, which would lead to confusion, the three specimens representing the test on one waterproofing material were averaged into a single curve. One curve for each material is drawn for the "dry weights," which is represented by the broken line, and one is drawn for the weights after 30 minutes immersion, which is represented by the solid line. By the expression "dry weights" is meant the weights before immersion in water. It will be noted that the curve of "dry weights" fluctuates in many cases to a considerable extent, which indicates that there was an absorption from rains. The actual dry weights of the specimens can be approximated in any case by drawing a straight line through the lowest points of the dotted curves. In order to obtain a definite basis for comparing the results obtained on different waterproofing materials, three values have been computed for each material and placed at the left of the curve. The significance of these values is as follows: $p=$ average percentage by weight of water contained by the specimens at the time of the first weighing; that is, it represents the water absorbed from rains; $q=$ average percentage by weight of water contained by the specimens after 30 minutes immersion; that is, it represents the sum of that absorbed from rains and that absorbed while immersed; $r=$ the highest percentage of water determined for the material in the entire series of tests.

It will be noted that in the longer period tests, there are a few duplications of the same material on different stones. These were originally meant for check tests, but they served another 
important purpose. They showed that the different treatments do not act with an equal degree of effectiveness on different textures. This led to a rather extensive series of tests on stones of varying texture. This series, which includes tests of all the waterproofing materials on three sandstones from Ohio, have extended over a period of six months.

The results of the latter series is shown in Figures 7, I0, and I I. Figure 7 shows the results of the materials on the fine-grained, close-texture stone; Figure ro the results on a more open texture; and Figure II the results on a stone of rather coarse texture. A more detailed description of the stone specimens will be found in the following section.

The rainfall during the periods of exposure is shown for each group of specimens by the curves starting at the lower left corner of each figure. The data for these curves were taken from the official records of the U. S. Weather Bureau station at Washington. It will be noted that these curves consist of a series of horizontal lines joined by vertical or diagonal lines. The horizontal lines represent periods of dry weather and the length of each referred to the time scale at the bottom of the charts indicates how long the dry period lasted. The vertical or diagonal lines indicate precipitation, which may be rain, snow, or sleet. Snow or sleet is reduced to the same basis as the rainfall by computing how many inches of water the melted snow or sleet would form. These vertical and diagonal lines show three things, viz: The vertical rise referred to the scale at the right gives the total amount of precipitation during the storm; the time of beginning of precipitation is indicated by the point where the curve begins to rise; the duration of the precipitation is roughly indicated by the horizontal projection on the time scale at the bottom. The total precipitation from the time any test was started to any particular time during the test may be obtained by reading on the scale at the right opposite the point in question.

\section{DESCRIPTION OF STONES USED IN THE TESTS.}

The ro samples of limestone were all from the region around Bedford and Bloomington, Ind., and are the well-known colitic limestones which are so extensively used in all parts of the country. The range in textures of these samples varied considerably. In Table I the textures are classified as "fine," "medium," and "coarse." This classification refers principally to the closeness 
of the grains, and the size of the pore spaces. By "fine" is meant very closely compacted grains with few open spaces between which are large enough to be readily seen.

Those referred to as "medium" are more open in appearance and unfilled spaces between the grains can be more readily discerned, while those of "coarse" textures are so open that the larger pore spaces can be seen at a distance of several feet.

The sandstones gave a somewhat wider range in textures than the limestones. The very fine-grained and firmly compacted stone (No. I3), from McDermott, Ohio, was considerably finer in texture than the limestones classed as fine. The sandstone from E1 Morro, N. Mex., was slightly coarser in texture than the McDermott stone and also somewhat finer than the finetexture limestones. The Mississippi sandstone is somewhat finer in texture than the medium limestones. The Amherst (No. I4) stone is about equivalent to the medium limestones, and the Glenmont stone is similar to the coarse-texture limestones, except that the pore spaces are more nearly uniform in size and distribution. The absorption and porosity values given in the table do not bear any definite relation to the texture of the stone. For instance, it is not always the stone of fine texture that has the least pore space. It frequently happens that a stone with large pores and coarse appearance will absorb less water than one with a fine-grained texture. In the case of the sandstones the closeness of texture appears to affect the rate of absorption to some extent; that is, the close textures absorb more slowly. It will be noted from the results given that the amount of water absorbed in 30 minutes amounts to between 0.6 and 0.9 of that absorbed in seven days. The absorption values are computed on the weight basis; that is, the weight of water absorbed was divided by the weight of the stone, while the porosity is expressed as a volume ratio. Hence, in order to compare the absorption values with the total pore space it is necessary to reduce them to the volume basis also. This is done by multiplying them by the apparent specific-gravity values of the stone, which varies between 2.20 and 2.40. For instance, in the case of stone No. I the absorption by weight is $5.5^{2}$ per cent. In order to determine the volume ratio; that is, the relation of the volume of absorbed water to the volume of the stone, one multiplies the above value by 2.20 (the apparent specific gravity of the stone). Thus: $5.52 \times 2.20=\mathrm{I} 2.24$. By comparing this with the porosity, viz: 16.92 , one finds that 
approximately three-fourths of the pore space, in this case, was filled during seven days immersion.

In Table I the stone samples are assigned serial numbers which are used throughout the text in referring to them.

TABLE 1.-Physical Properties of Stone Specimens.

\begin{tabular}{|c|c|c|c|c|c|c|c|}
\hline \multirow{2}{*}{$\begin{array}{c}\text { Sam- } \\
\text { ple } \\
\text { num- } \\
\text { ber. }\end{array}$} & \multirow{2}{*}{ Type of stone. } & \multirow{2}{*}{ Location of quarry. } & \multirow{2}{*}{ Color. } & \multirow{2}{*}{ Texture. } & \multicolumn{2}{|c|}{$\begin{array}{c}\text { Percentage of water } \\
\text { absorption. }\end{array}$} & \multirow[b]{2}{*}{ Porosity. ${ }^{1}$} \\
\hline & & & & & $\begin{array}{c}\text { 30-minute } \\
\text { immer- } \\
\text { sion. }\end{array}$ & $\begin{array}{l}\text { 7-days } \\
\text { Immer- } \\
\text { slon. }\end{array}$ & \\
\hline $\begin{array}{l}1 \ldots \ldots \\
2 \ldots \ldots \\
3 \ldots \ldots \\
4 \ldots . \\
5 \ldots\end{array}$ & 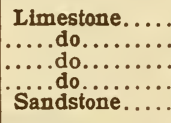 & 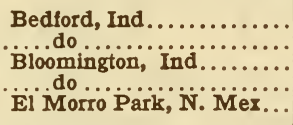 & $\begin{array}{l}\text { Buff..... } \\
\ldots \text { do } \ldots . . . \\
\ldots \text { do } \\
\text { Gray....... }\end{array}$ & $\begin{array}{l}\text { Fine } \ldots . . . \\
\text { Codo } \ldots . . . . \\
\text { Medium... } \\
\text { Fine ....... }\end{array}$ & $\begin{array}{l}4.49 \\
3.16 \\
5.44 \\
5.59 \\
1.94\end{array}$ & $\begin{array}{l}5.52 \\
5.18 \\
6.43 \\
5.87 \\
3.24\end{array}$ & $\begin{array}{l}16.92 \\
15.44 \\
17.28 \\
17.28 \\
\cdots \cdots\end{array}$ \\
\hline $\begin{array}{r}6 \ldots . . \\
7 \ldots \\
8 \ldots . \\
9 \ldots \\
10 \ldots\end{array}$ & $\begin{array}{l}\text { Limestone. ... } \\
\text { Sandstone..... } \\
\text { Limestone...... } \\
\ldots \ldots \text {. do } \ldots \ldots \ldots \ldots \\
\ldots \ldots \text { do........... }\end{array}$ & 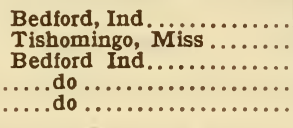 & $\begin{array}{l}\text { Buff .... } \\
\text { Gray.... } \\
\text { Buff .... } \\
\text { Gra..... }\end{array}$ & $\begin{array}{l}\text { Coarse.... } \\
\text { Medium.. } \\
\text { Fine } \ldots \ldots . . \\
\ldots \text { do } \ldots \ldots . . \\
\ldots \text { do } \ldots \ldots .\end{array}$ & $\begin{array}{l}4.42 \\
4.13 \\
3.98 \\
2.28 \\
3.65\end{array}$ & $\begin{array}{l}4.60 \\
6.34 \\
4.49 \\
3.97 \\
4.32\end{array}$ & $\begin{array}{l}14.70 \\
13.70 \\
14.70 \\
14.70\end{array}$ \\
\hline $\begin{array}{l}11 \ldots \\
12 \ldots \\
13 \ldots \\
14 \ldots \\
15 \ldots\end{array}$ & 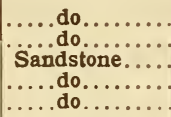 & 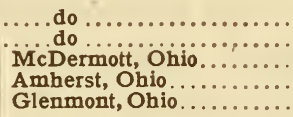 & $\begin{array}{l}\ldots \text { do } \ldots . . . \\
\text { Bdo...... } \\
\text { Gray..... } \\
\text { Buff.... }\end{array}$ & $\begin{array}{l}\text { Medium.... } \\
\text { Fine ...... } \\
\text { Medium.. } \\
\text { Coarse.... }\end{array}$ & $\begin{array}{l}2.56 \\
3.57 \\
3.54 \\
5.00 \\
6.36\end{array}$ & $\begin{array}{l}3.48 \\
4.02 \\
5.39 \\
6.66 \\
7.24\end{array}$ & $\begin{array}{l}12.88 \\
13.97 \\
17.37 \\
18.68 \\
21.72\end{array}$ \\
\hline
\end{tabular}

$1 \mathrm{By}$ porosity is meant the total volume of the pores times roo divided by the volume of the stone. The values were determined by making both true and apparent specific gravity tests. From these values the porosity was calculated as follows:

$$
\text { Porosity }=\frac{\text { true specific gravity-apparent specific gravity }}{\text { true specific gravity }} \times \text { roo. }
$$

\section{DESCRIPTION OF WATERPROOFING MATERIALS.}

The treatments employed in this investigation consist of 20 proprietary materials, I proprietary process, and 2 nonproprietary processes. The proprietary materials were submitted by the producers, and the others were made up in the laboratory. For the later tests a new set of proprietary samples were requested, and when these were analyzed some were found to differ considerably in composition from those of the same name in the first set. In one case a material had been taken over by another firm and changed in name and composition. The materials are referred to in this report by reference letters; that is, A, B, C, etc. In the second set of samples the materials are referred to as $A^{\prime}, B^{\prime}, C^{\prime}$, etc., in which $A^{\prime}$ is of the same trade name as $A$, $\mathrm{B}^{\prime}$ the same as $\mathrm{B}$, and so on.

The trade names of the materials used in these tests are as follows: Lithol, minwax, clear driwal, G. F. roo, G. F. I45, ceresitol, cresolac, aquabar No. 2, kemisol, dehydratine No. 2, dehydratine No. 22, dehydratine No. 222, colorless waterproofing, 
Glidden's colorless waterproofing, anhydrosol, toxloxpore, reduced I,or 7, Caffall's process, porseal, Sylvester's process, gar-kem, and pyramid.

The greater number of these materials are thin liquids which are applied to the surface of the stone in the same manner as paint. Some are almost as clear as water, others have a yellowish or brownish color, while a few are milky white. One consists of paraffin alone, which is melted and applied by a process involving considerable skill and experience, hence it should be considered as a proprietary process rather than a proprietary material.

The materials may be divided into various groups, according to their composition. The following divisions have been adopted in this report for convenience in describing the results:

Group r.-Petroleum distillates (including paraffin), fatty substances, and mixtures of the two dissolved in mineral spirits. The petroleum distillates consist of paraffin or similar fractions and the mineral spirits are the light distillates of petroleum. A fatty substance frequently found in these materials is china wood oil.

When these materials are applied to a stone they penetrate into the pores, and as the light volatile solvents evaporate a considerable portion of the waxy or fatty substances held in solution is deposited in the pores. This nonvolatile substance constitutes the waterproofing element; that is, it tends to seal up the pores and prevents or retards the absorption of water.

GROUP 2.-Aluminum soap or a mixture thereof with heavy petroleum distillates, fatty or resinous substances dissolved in mineral spirits, coal-tar naphtha, or turpentine. These materials act in a similar manner to those in Group I.

Group 3:-Resinous materials and mixtures of same with fatty oils dissolved in mineral spirits or coal-tar naphtha. These penetrate the pores to a slight extent and usually deposit a thin film on the surface. They are really light varnishes.

GROUP 4.-Water solutions of various substances which are claimed to react chemically with some element in the stone and form pore-filling substances. The substances used in this group consist of inorganic salts, glue, and soluble soaps.

Group 5.-Two aqueous solutions which are applied as individual treatments and react chemically with each other precipitating an insoluble substance in the pores. A typical example of this class consists of a solution of alum, followed by a solution $63649^{\circ}-24-2$ 
of soft soap, which results in the formation of an insoluble soap. This treatment accomplishes the same object as some of the treatments in Group 2; that is, it deposits aluminum soap in the pores. Other treatments of this nature were tried in a preliminary way, but the results were not promising, so they were not included in the exposure tests. They were as follows: Sodium silicate and calcium chloride, sodium silicate and limewater, and calcium chloride and soft soap.

Two treatments were included which do not fall under any of the classifications above, hence they are described separately. Treatment $J$ is a solution of cellulose nitrate in a solvent similar to fusel oil. The material is of a sirupy nature and does not penetrate the pores to any appreciable extent, but leaves a thin film on the surface. The other is the molten-paraffin process mentioned above. It attains the same object as some of the materials in Group I which carry the paraffin into the pores in solution where it remains after the solvents evaporate.

Several of these materials are not very stable even in the containers. All have to be kept sealed; that is, air-tight, else the solvent will soon evaporate, leaving the nonvolatile matter as a solid mass. Even in sealed containers a considerable number of the treatments tend to separate after a few months, leaving the solids at the bottom or on the sides of the container. This is especially true of those materials which carry fatty substances and aluminum soap in solution. Those which have only paraffin in solution appear to be the most stable among the organic compounds. The water solutions are fairly stable, except those containing glue which were found to decompose in some cases.

The materials in Groups I and 2, especially those containing a large percentage of nonvolatile matter in solution, become very thick and even solid in cold weather. At $50^{\circ} \mathrm{F}$. materials $\mathrm{B}, \mathrm{I}$, $\mathrm{M}$, and D practically lose their mobility, and others of the first two groups become too thick to apply effectively. It is believed that these materials should not be applied at temperatures below $70^{\circ} \mathrm{F}$. Another point which greatly affects the penetration of the materials is the dryness of the stone. Damp surfaces will not absorb the treatments properly, hence they should be applied during dry weather. 


\section{COMPOSITION OF MATERIALS.}

On account of the nature of these materials, viz: The volatility of the solvents and the tendency of the nonvolatile matter to change or precipitate on standing, the chemical analyses may not indicate the exact proportions which were originally used. Hence, the results are given in round numbers, and are merely intended to show the general nature of the materials and serve as a basis of classification.

GROUP I.-Petroleum distillates and fatty substances dissolved in mineral spirits.

\section{Material M:}

Color. Clear, slightly yellow.

Odor. . Mineral spirits.

Consistency Thin liquid.

Volatile $\left(24\right.$ hours at $105^{\circ} \mathrm{C}$.) 86 per cent. Character Mainly mineral spirits.

Nonvolatile $\left(24\right.$ hours at $105^{\circ} \mathrm{C}$.) I4 per cent.

Character. Paraffin.

Material M':

Color. Clear, water white.

Odor. Mineral spirits.

Consistency Very thin liquid.

Volatile $\left(24\right.$ hours at $105^{\circ} \mathrm{C}$. 88 per cent.

Character. Mineral spirits.

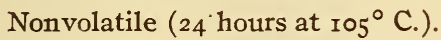
I2 per cent. Character. Chiefly paraffin. Material S:

Color Cloudy.

Odor. Mineral spirits.

Consistency Thin liquid.

Volatile $\left(24\right.$ hours at $105^{\circ} \mathrm{C}$ ) $\ldots \ldots \ldots \ldots \ldots \ldots \ldots 9$ per cent.

Character. Mainly mineral spirits.

Nonvolatile $\left(24\right.$ hours at $105^{\circ} \mathrm{C}$.) 7 per cent. Character. Paraffin. Material S':

Color . Water white.

Odor . . . . . . . . . . . . . . . . .

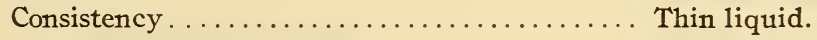

Volatile $\left(24\right.$ hours at $105^{\circ}$ C. $) \ldots \ldots \ldots \ldots \ldots .85$ per cent.

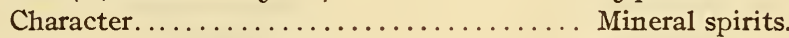

Nonvolatile $\left(24\right.$ hours at $105^{\circ} \mathrm{C}$. $) \ldots \ldots \ldots \ldots \ldots$ I 5 per cent. Character................... Paraffin.

Material U:

This treatment was made up in the laboratory and consisted of approximately a ro per cent solution of paraffin in gasoline. 
Material B:

Color............................ Clear yellow.

Odor. . . . . . . . . . . . . . . . . . . . . . .

Consistency...................... Thin liquid.

Volatile $\left(24\right.$ hours at $105^{\circ} \mathrm{C}$.)..............6. 67 per cent.

Character....................... Mineral spirits.

Nonvolatile $\left(24\right.$ hours at $105^{\circ} \mathrm{C}$.)......... 33 per cent.

Material $\mathrm{B}^{\prime}$ :

Character........................ China wood oil and paraffin.

Color............................ Clear yellow.

Odor............................... Mineral spirits.

Consistency.............................. Thin liquid.

Volatile $\left(24\right.$ hours at $105^{\circ} \mathrm{C}$. $) \ldots \ldots \ldots \ldots \ldots 67$ per cent.

Character......................... Mineral spirits.

Nonvolatile (24 hours at $105^{\circ} \mathrm{C}$.) $\ldots \ldots \ldots \ldots 33$ per cent.

Material I:

Character........................ China wood oil and paraffin.

Color . . .......................... Light amber.

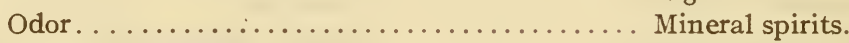

Consistency....................... Thin liquid.

Volatile $\left(24\right.$ hours ai $105^{\circ} \mathrm{C}$.)...........6. 62 per cent.

Character....................... Petroleum distillate.

Nonvolatile $\left(24\right.$ hours at $105^{\circ} \mathrm{C}$.).............. 38 per cent.

Character....................... Fatty oil and paraffin.

Material I':

Color . . . . . . . . . . . . . . . . . . . . . . . .

Odor.................................... China wood oil.

Consistency ....................... Thin liquid.

Volatile $\left(24\right.$ hours at $\left.105^{\circ} \mathrm{C}.\right) \ldots \ldots \ldots \ldots \ldots 26$ per cent.

Character....................... Petroleum distillate.

Nonvolatile $\left(24\right.$ hours at $105^{\circ} \mathrm{C}$ ) $\ldots \ldots \ldots \ldots, 74$ per cent.

Material D:

Character......................... China wood oil and paraffin.

Color.

Light yellow.

Odor................................. China wood oil.

Consistency.......................... Thin liquid.

Volatile $\left(24\right.$ hours at $105^{\circ} \mathrm{C}$.) $\ldots \ldots \ldots \ldots \ldots$. 90 per cent.

Character......................... Nineral spirits.

Nonvolatile $\left(24\right.$ hours at $105^{\circ} \mathrm{C}$.) $\ldots \ldots \ldots \ldots$.

Character........................ Mainly fatty oil.

Material $\mathrm{D}^{\prime}$ :

Color.

Dark yellow, cloudy.

Odor. Mineral spirits.

Consistency

Thin liquid.

Volatile (24 hours at $105^{\circ} \mathrm{C}$.)

24 per cent.

Character.

Mineral spirits.

Nonvolatile $\left(24\right.$ hours at $105^{\circ} \mathrm{C}$.) 76 per cent.

Character.

China wood oil and paraffin. 
Material $\mathrm{O}^{\prime}$ :

Color.......................... Clear yellow.

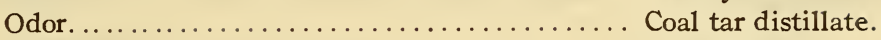

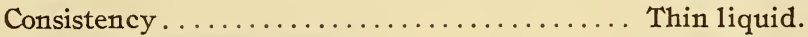

Volatile $\left(24\right.$ hours at $105^{\circ}$ C. $) \ldots \ldots \ldots \ldots \ldots \ldots 93$ per cent.

Character........................... tal and petroleum distillates.

Nonvolatile $\left(24\right.$ hours at $105^{\circ} \mathrm{C}$. $) \ldots \ldots \ldots \ldots \ldots 7$ per cent.

Character.............................. phiefly paraffin, some fatty

Material A: matter present.

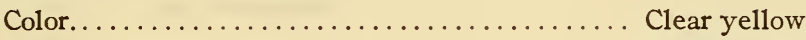

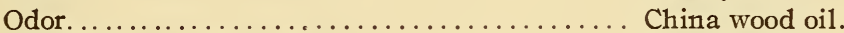

Consistency....................... Thin liquid.

Volatile $\left(24\right.$ hours at $105^{\circ} \mathrm{C}$. $) \ldots \ldots \ldots \ldots \ldots \ldots \ldots \ldots \ldots$ per cent.

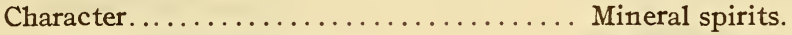

Nonvolatile $\left(24\right.$ hours at $105^{\circ}$ C. $) \ldots \ldots \ldots \ldots \ldots 27$ per cent.

Material $\mathrm{A}^{\prime}$ :

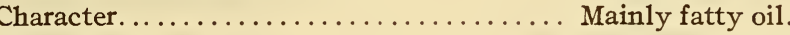

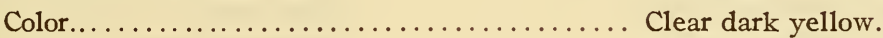

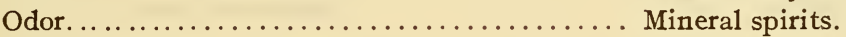

Consistency........................ Thin liquid.

Volatile $\left(24\right.$ hours at $105^{\circ} \mathrm{C}$. $) \ldots \ldots \ldots \ldots \ldots \ldots 82$ per cent.

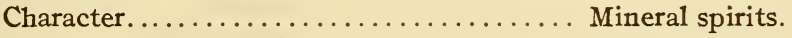

Nonvolatile $\left(24\right.$ hours at $\left.105^{\circ} \mathrm{C}.\right) \ldots \ldots \ldots \ldots \ldots$ I 8 per cent.

Material G:

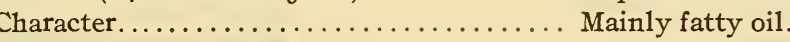

Color.

Clear yellow.

Odor. Nitrobenzol.

Consistency....................... Very thin liquid.

Volatile. 88 per cent.

Character....................... Petroleum distillate

Nonvolatile $\left(48\right.$ hours at $105^{\circ} \mathrm{C}$.)........... r2 per cent.

Character.................... Soft petroleum grease

On further heating a ro $\mathrm{g}$ sample of this material at $105^{\circ} \mathrm{C}$. for six days, 99 per cent volatilized, leaving a soft sticky residue of I per cent.

Material $\mathrm{G}^{\prime}$ :

Color.

Clear amber.

Odor.

Petroleum distillate.

Consistency

Very thin, sirupy.

Volatile (I44 hours at $105^{\circ} \mathrm{C}$.)

84 per cent.

Character.

Petroleum distillate.

Nonvolatile ( 144 hours at $105^{\circ}$ C.) r6 per cent.

Character.

Mainly fatty oil. 
GROUP 2.-Aluminum soap or a mixture of same with petroleum distillates, fatty, or resinous substances dissolved in mineral spirits, coal-tar naphtha, or turpentine.

Material C:

Color............................. Cloudy brown.

Odor........................... Varnish like.

Consistency....................... Thin liquid.

Volatile $\left(24\right.$ hours at $105^{\circ} \mathrm{C}$.)............. $9^{6}$ per cent.

Character....................... Mainly mineral spirits.

Nonvolatile $\left(24\right.$ hours at $105^{\circ} \mathrm{C}$.) $\ldots \ldots \ldots \ldots, 4$ per cent.

Ash (aluminum oxide) ................ I3 per cent.

Character....................... Aluminum soap.

Material $\mathrm{C}^{\prime}$

Color............................ Cloudy yellow.

Odor............................. Turpentine.

Consistency....................... Thin sirupy liquid.

Volatile $\left(24\right.$ hours at $105^{\circ} \mathrm{C}$.) $\ldots \ldots \ldots \ldots \ldots, 96$ per cent.

Character....................... Turpentine-mineral spirits.

Nonvolatile $\left(24\right.$ hours at $105^{\circ} \mathrm{C}$.) .......... 4 per cent.

Ash (aluminum oxide) ............... I 8 per cent.

Character....................... Aluminum soap.

Material $\mathrm{F}^{\prime}$ :

Color ............................ Cloudy, dirty yellow.

Odor ................................ Benzol.

Consistency ..................... Thin liquid.

Volatile $\left(24\right.$ hours at $105^{\circ} \mathrm{C}$.) $\ldots \ldots \ldots \ldots \ldots, 97$ per cent.

Character........................ Mainly mineral spirits.

Non volatile $\left(24\right.$ hours at $105^{\circ} \mathrm{C}$. $) \ldots \ldots \ldots \ldots, 3$ per cent.

Ash (aluminum oxide)................ 6.4 per cent.

Character....................... Aluminum soap and waxy material.

Material $\mathrm{K}^{\prime}$ :

Color ............................. Milky.

Odor ............................. Coal-tar distillate.

Consistency....................... A viscous liquid which sepa. rates on standing.

Volatile $\left(24\right.$ hours at $105{ }^{\circ} \mathrm{C}$ ) $\ldots \ldots \ldots \ldots \ldots, 7$ I per cent.

Character....................... Chiefly coal-tar distillate.

Nonvolatile $\left(24\right.$ hours at $105^{\circ} \mathrm{C}$.) . . . . . 29 per cent.

Ash (aluminum oxide)............... 7.2 per cent.

Character............................ Fatty oil and aluminum soap.

Material L:

Color.

Dark brown.

Odor ............................... Petroleum distillate.

Consistency........................ Thin liquid.

Volatile $\left(24\right.$ hours at $105^{\circ} \mathrm{C}$. $) \ldots \ldots \ldots \ldots \ldots, 93$ per cent.

Character........................ Petroleum distillate.

Nonvolatile $\left(24\right.$ hours at $105^{\circ} \mathrm{C}$. $) \ldots \ldots \ldots \ldots, 7$ per cent.

Rosin test...................... Positive.

Ash (aluminum oxide)................ 6.4 per cent.

Character......................... Mainly aluminum soap. 
Material L':

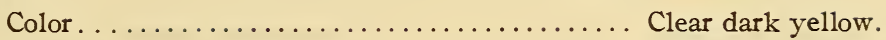

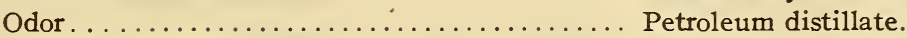

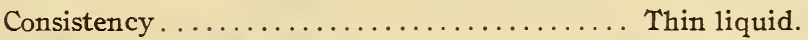

Volatile $\left(24\right.$ hours at $\left.105^{\circ} \mathrm{C}.\right) \ldots \ldots \ldots \ldots \ldots . \ldots 8$ per cent.

Character..................... Petroleum distillate.

Nonvolatile $\left(24\right.$ hours at $105^{\circ}$ C. $) \ldots \ldots \ldots \ldots$ I2 per cent.

Ash (aluminum oxide)............. 2.4 per cent.

Character....................... Aluminum soap and heavy

mineral oil.

Material V:

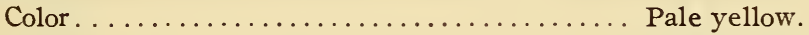

Odor. ........................ Turpentine.

Consistency..................... Thin liquid.

Volatile $\left(24\right.$ hours at $105^{\circ}$ C. $) \ldots \ldots \ldots \ldots \ldots \ldots 9$ per cent.

Character.................... Turpentine and petroleum distillate.

Nonvolatile $\left(24\right.$ hours at $105^{\circ}$ C. $) \ldots \ldots \ldots \ldots .5$ per cent.

Rosin test.................... Positive.

Ash (aluminum oxide).............. 9.I per cent.

Character.................... Mainly aluminum soap.

Material $\mathrm{K}$ :

GROUP 3.-Materials of a varnish nature.

Color.

Yellowish brown.

Odor . . . . . . . . . . . . . . . . . . . . . Coal-tar distillate.

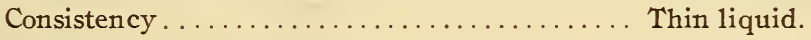

Volatile $\left(24\right.$ hours at $105^{\circ}$ C. $) \ldots \ldots \ldots \ldots \ldots 66_{2}$ per cent.

Character...............................

Nonvolatile $\left(24\right.$ hours at $105^{\circ}$ C. $) \ldots \ldots \ldots \ldots 3^{8}$ per cent.

Character.................... Coal-tar resin.

Material O:

Color .

Clear dark amber.

Odor.

Varnish.

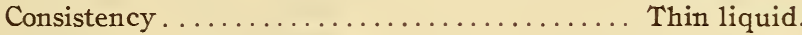

Volatile $\left(24\right.$ hours at $\left.105^{\circ} \mathrm{C}.\right) \ldots \ldots \ldots \ldots \ldots$. 6 I per cent.

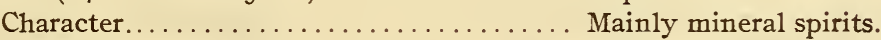

Nonvolatile $\left(24\right.$ hours at $105^{\circ}$ C. $) \ldots \ldots \ldots \ldots$ per cent.

Character................... Oils and resins.

Rosin test...................... Positive.

Material P:

Color.

Clear dark amber.

Odor.

Varnish.

Consistency ........................ Thin liquid.

Volatile $\left(24\right.$ hours at $105^{\circ}$ C. $) \ldots \ldots \ldots \ldots \ldots 62$ per cent.

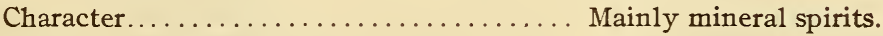

Nonvolatile $\left(24\right.$ hours at $105^{\circ}$ C. $) \ldots \ldots \ldots \ldots .38$ per cent.

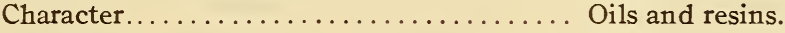

Rosin test................... Positive. 
Material Q:

Color. Clear dark yellow.

Odor. Varnish.

Consistency Thin liquid.

Volatile (24 hours at $105^{\circ} \mathrm{C}$.) 68 per cent. Character. Mainly mineral spirits.

Nonvolatile $\left(24\right.$ hours at $105^{\circ} \mathrm{C}$.) . . . . . . 32 per cent. Character....................... Oils and resins.

Rosin test. Positive.

Group 4.-Inorganic salts, soluble soap or glue dissolved in water.

Material E:

A I 5 per cent aqueous solution of magnesium fluosilicate. Material $\mathrm{F}$ :

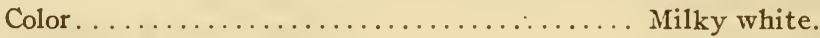

Odor............................ Ammonia.

Consistency ....................... Thin liquid.

Volatile $\left(24\right.$ hours at $105^{\circ} \mathrm{C}$.) . . . . . . . . 97 per cent.

Character......................... Water and ammonia.

Nonvolatile $\left(24\right.$ hours at $105^{\circ} \mathrm{C}$.) . . . . . . 3 per cent.

Fatty matter................... 94.7 per cent.

Ash (mainly sodium carbonate)......... 5.3 per cent.

Character....................... Sodium-ammonium soap.

Material $\mathrm{H}$ :

Color............................. Milky white.

Odor............................ Glue.

Consistency........................ Thin liquid.

Volatile $\left(24\right.$ hours at $105^{\circ} \mathrm{C}$.) . . . . . . . . 94 per cent. Character......................... Water.

Nonvolatile $\left(24\right.$ hours at $105^{\circ} \mathrm{C}$.) . . . . . . 6 per cent. Character........................ Mainly glue.

\section{Material $\mathrm{H}^{\prime}$}

Color. . Milky white.

Odor. Glue.

Consistency...................... Thin liquid.

Volatile $\left(24\right.$ hours at $105^{\circ} \mathrm{C}$. $) \ldots \ldots \ldots \ldots, 97$ per cent. Character........................ Water.

Nonvolatile $\left(24\right.$ hours at $105^{\circ} \mathrm{C}$.) . . . . . . 3 per cent. Ash (aluminum oxide) ................ II per cent.

Character.

Glue, waxy material, and aluminum soap.

Material W:

Color Milky white.

Odor Rancid fat.

Consistency Thin liquid.

Volatile at $105^{\circ} \mathrm{C}$ 95 per cent.

Character.

Water.

Nonvolatile. 5 per cent.

Character. Glue with a small amount of aluminum soap and borax. 
GROUP 5.-Two aqueous solutions which react with each other and precipitate a non-

Material T: soluble substance.

This is a nonproprietary process known as Sylvester's process. The materials consist of 2 ounces of alum dissolved in I gallon of water for the first application and I2 ounces of soft soap dissolved in I gallon of water for the second coat. The reaction results in the formation of an aluminum soap.

Miscellaneous.

Material J:

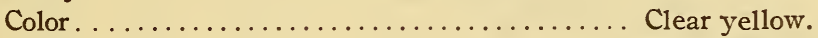

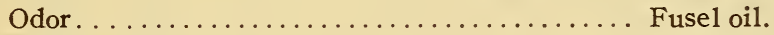

Consistency ........................ Sirupy liquid.

Volatile $\left(24\right.$ hours at $105^{\circ} \mathrm{C}$.) $\ldots \ldots \ldots \ldots \ldots, 93$ per cent.

Character......................... Ethyl acetate, acetone, etc.

Nonvolatile $\left(24\right.$ hours at $105^{\circ} \mathrm{C}$. $) \ldots \ldots \ldots \ldots, 7$ per cent.

Character.......................... Mainly cellulose nitrate.

Material J':

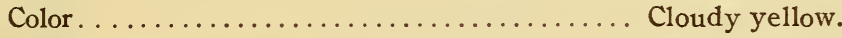

Odor............................ Amyl acetate.

Consistency........................ Sirupy liquid.

Volatile $\left(24\right.$ hours at $105^{\circ} \mathrm{C}$.) ............. 90 per cent.

Character........................ Amyl acetate and fusel oil.

Nonvolatile $\left(24\right.$ hours at $105^{\circ} \mathrm{C}$. $) \ldots \ldots \ldots$. Io per cent.

Material R:

Character.......................... Mainly cellulose nitrate.

This is a process rather than a material. The material used in treating the specimens was ordinary "parowax."

\section{RESULTS OF TESTS ON THE LONG-PERIOD EXPOSURES.}

A casual study of the curves given for the various materials in Figures 2, 3. 4, 5, 6, 7, I0, and I indicates that only a few of the treatments are effective in preventing water absorption over a period of several months' exposure. The few cases in which the two curves, viz: The "dry-weight" curves and the wet-weight curves, remain practically parallel and only slightly separated over a two-year period seem to indicate that a practical stone preservative is possible. Five proprietary materials showed little or no signs of deterioration, as far as the absorption values are concerned, during the period of these tests. Certain materials, such as M, Figure 3, were less effective during the first few months than later on. After four months exposure the absorption from a rain was rather high, but thereafter no appreciable absorption was noted. This is better shown by the last two sets of curves in Figure 5. These two treatments were made up in the laboratory; $\mathrm{U}_{1}$ consisting of one application and $\mathrm{U}_{2}$ of two applications of a ro per cent solution of paraffin in gasoline. Between three $63649^{\circ}-24-3$ 
and seven months after application these two treatments permitted considerable absorption during the immersion tests. After seven months both treatments gave very satisfactory results. So

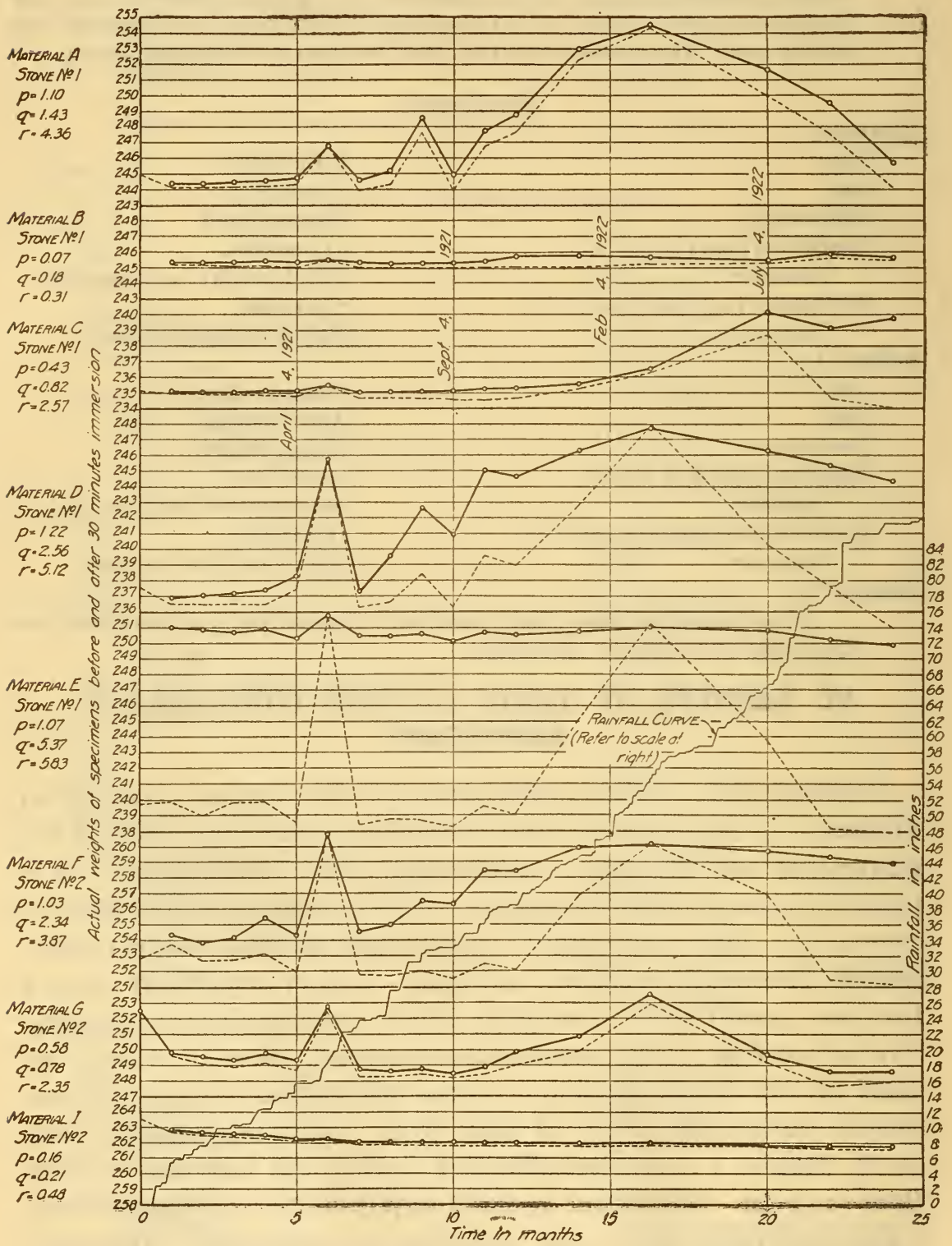

FIG. 2.-Results of absorption tests of eight waterproofing materials on Indiana limestone during an exposure period of two years.

far as this was noted it occurred only with those materials in which the solid matter was entirely paraffin. It has also been noted that if absorption tests are made within a few days after 
the specimens are treated there will be a higher absorption than at the end of a week or a month. This seems to be the case with all the materials in the first two groups as listed in Table 3.

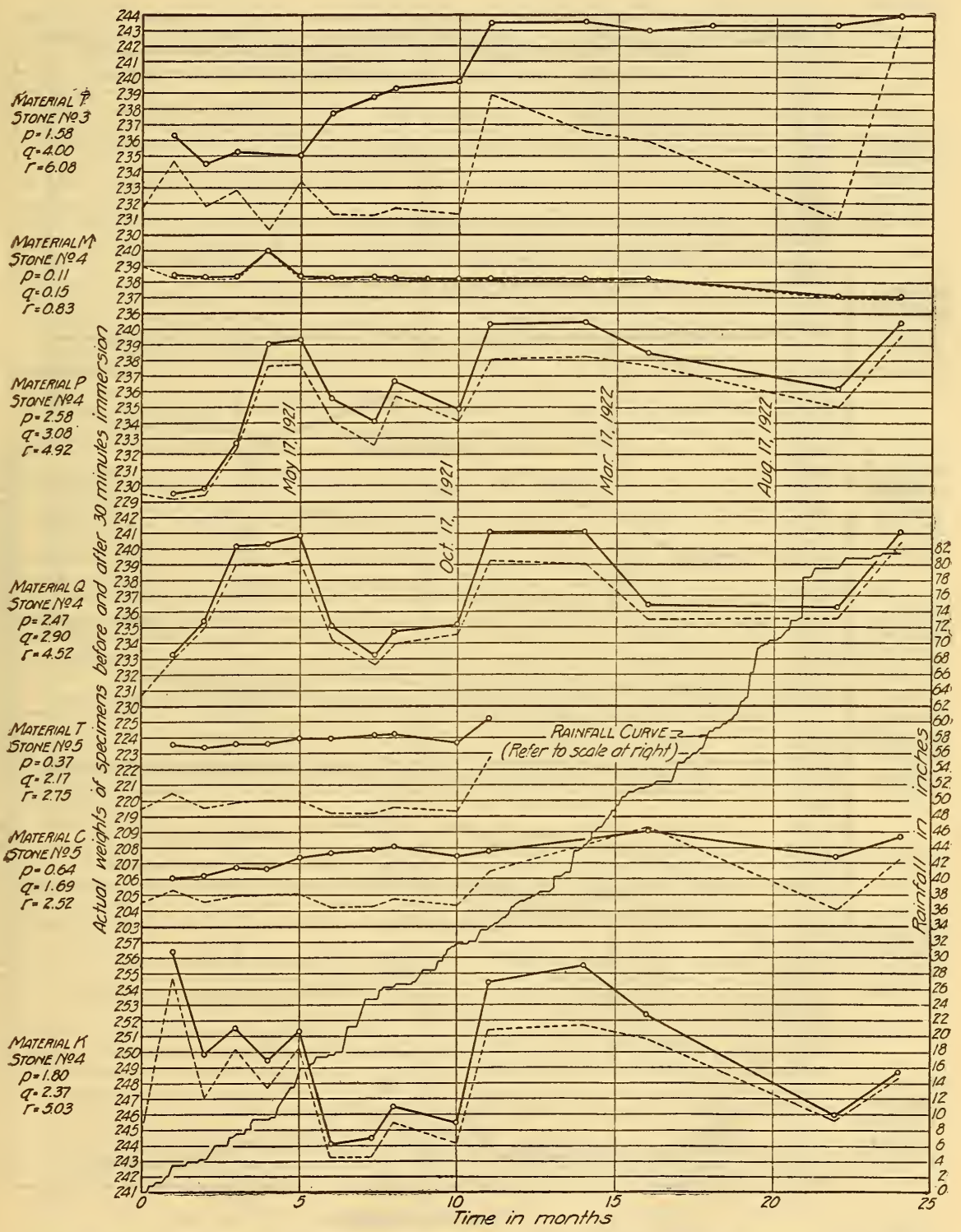

FIG. 3.-Results of absorption tests of six waterproofing materials on Indiana limestone and New Mexico sandstone during an exposure period of two years.

In the long-period tests one set of specimens of Indiana limestone (stone No. 6) and one set of the Mississippi sandstone were run without any waterproofing treatment. The results obtained 
on these are shown by the first curves in Figures 4 and 5. These afford a basis for judging the effects of the waterproofing materials. The upper curve, which represents the weights after 30 minutes

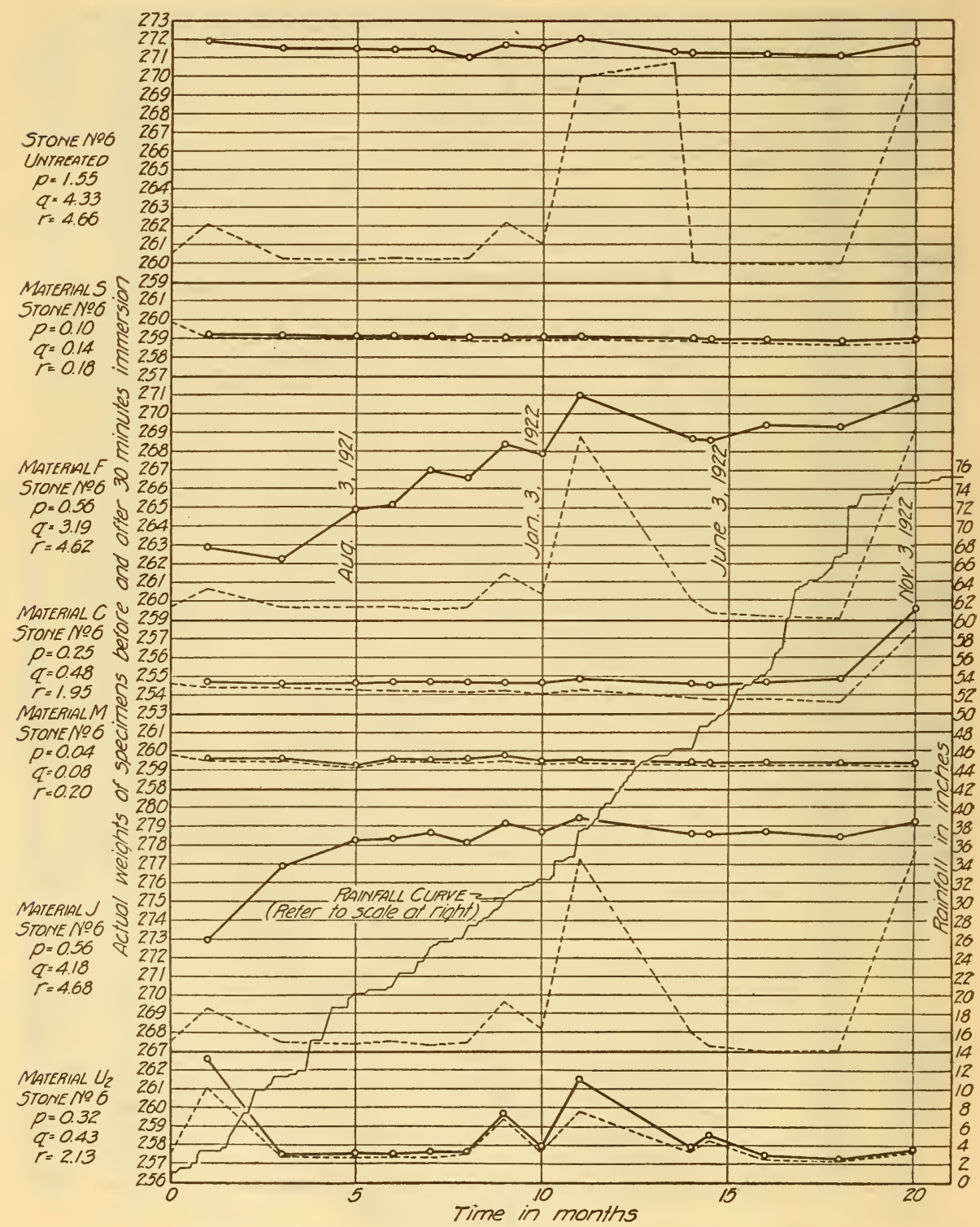

FIG. 4.-Results of absorption tests on treated and untreated specimens of Indiana limestone during an exposure period of two years.

immersion, has a general horizontal direction, and is considerably above the "dry-weight" curve the greater part of the time. Whenever these specimens were weighed on a rainy day or shortly 
after a rain the dotted curves are seen to rise sharply, often to the height of the "wet-weight" curves, and sometimes slightly above. This indicates that there was occasionally a greater absorption from heavy rains or long, slow rains than was absorbed during 30 minutes immersion, and that the specimens actually lost weight while immersed in water. This was probably due to a change in the temperature of the specimens between the first and second weighings. Occasionally during cold rains the specimens were brought into the laboratory for absorption tests when the outside temperature was near $32^{\circ} \mathrm{F}$. Not being entirely saturated with water the pores contained some air. It is believed that the expansion of this included air during the 30 minutes immersion in water was sometimes sufficient to force out some of the water absorbed from the rain. This condition was noted several times throughout the tests, on the treated specimens as well as on the untreated. Another feature of the tests on untreated specimens is worthy of note, viz: That on the sandstone a line drawn through the lowest weights in the "dry-weight" curve is practically horizontal, but one drawn similarly for the limestone shows a gradual drop with the period of exposure. This drop is believed to represent the amount of limestone which was dissolved and carried away by rain water. The appearance of the limestone specimens also seems to indicate an appreciable amount of surface solution, as the fossils are more distinct, and appear to stand out in relief to a certain extent. The sandstone being composed of a much less soluble material does not suffer this loss.

All of the treated specimens showed a considerable loss in weight during the early period of exposure, except those treated with molten paraffin. This is evidently due to the evaporation of the solvents of the waterproofing. The specimens were dried in the laboratory air for about a week before they were put out on the roof, but there seems to be a gradual evaporation for a month or more.

The gradual loss in weight over the entire period of exposure was noted for all the limestone specimens, whether treated or untreated. The loss on the treated specimens might be construed as being due to the evaporation or decomposition of the treatment. But this is disproved by the fact that the dry weights during the later part of the exposure periods were frequently less than the original weights of the untreated specimens. Furthermore, in sev- 
eral cases, we see that the waterproofing material is still functioning as well at the end of 20 months or longer as in the beginning. This indicates that even the materials which have high waterproofing values do not prevent surface solution on carbonate stones.

In general, it will be noted that all the materials which consist of solutions of fatty oils, aluminum soap, and paraffin, or a combination of these give fairly satisfactory results over a period of several months. At the end of a year or less those materials having fatty oil alone, or in large part, began to show signs of decay. Materials A and D in Figure 2 are examples of this type. The first, after passing a period of almost worthlessness between I 2 and 20 months, seems to have improved somewhat. This is probably due to a readjustment of the wax in the pores of the stone in the hot weather. Material D shows a similar condition, but the improvement at the end of the period is very slight.

Material G, which consists of a petroleum grease dissolved in mineral spirits, gave results very similar to the two mentioned above, but the absorption of this was considerably less and the treatment seems to be somewhat more durable.

Those materials having chiefly aluminum soap for the waterproofing element gave good results during the greater portion of the period, but show a considerable deterioration during the later months. This is illustrated by the gradual separation of the curves for material $\mathrm{C}$ in Figure 2 and to a less extent by material $\mathrm{L}$ in Figure 5. The other materials of this group have not been under test longer than eight months and do not show any definite deterioration.

The materials which have paraffin for the solid matter, either entirely or in part, have shown the highest waterproofing values and the least deterioration. Those having a mixture of paraffin and fatty oil, viz: Materials B and I, gave excellent results on Indiana limestone. Curves for these are shown in Figure 2. Those having all paraffin for their solid matter also gave highly satisfactory results in most cases, except for a few instances of minor relapse in the early part of the tests as noted above. Materials of this type are M, S, and U. Treatment R, which consists entirely of paraffin, is distinguished from the others by the fact that it has no solvent, but consists of the wax applied hot. It is a proprietary process rather than a proprietary material. The only long-period test made with this treatment was on the fine-grained sandstone from New Mexico. The curves for this 
test are not shown, due to the fact that they were started at an earlier date, and, hence, could not be grouped with other curves. This test was not satisfactory, as the specimens absorbed con-

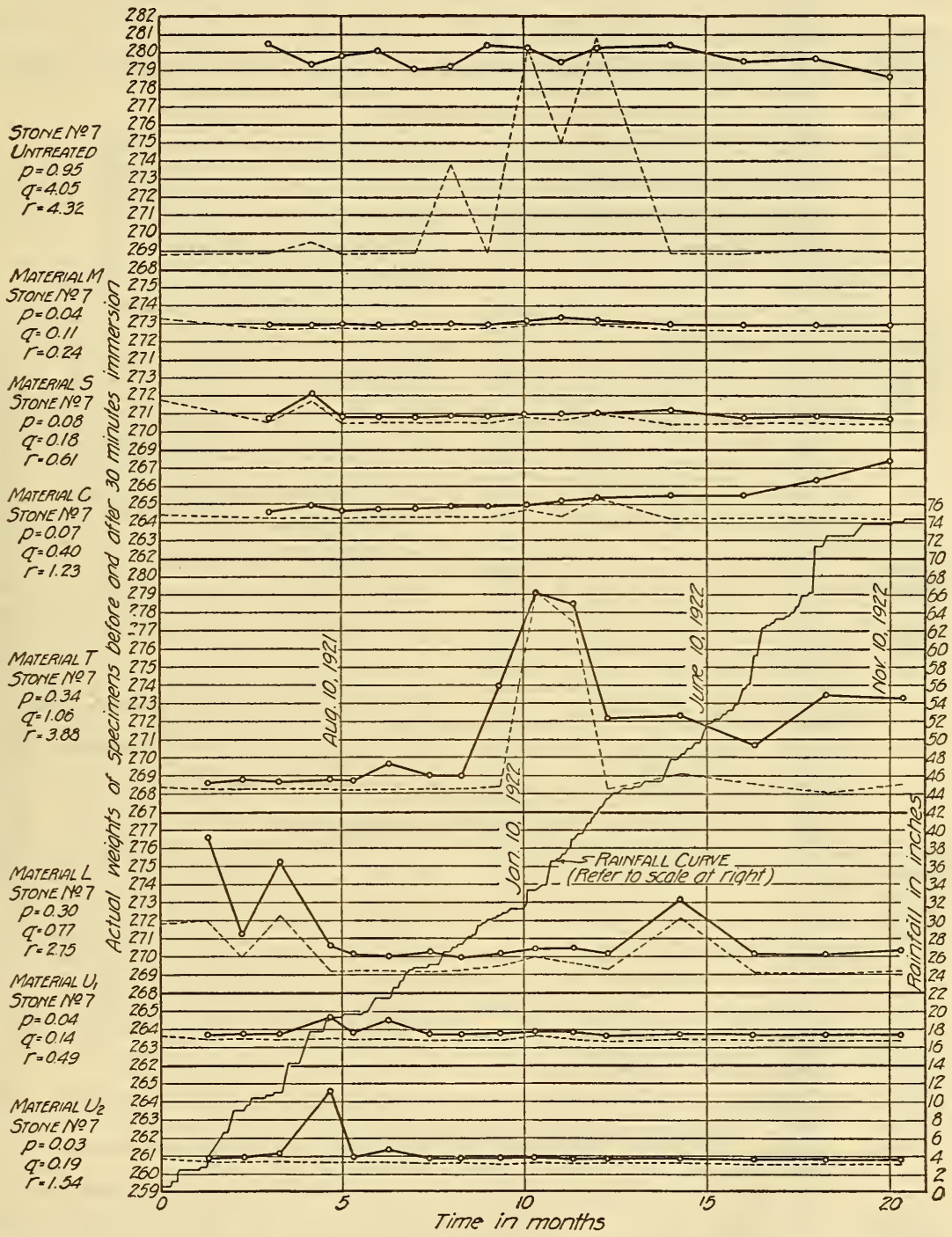

FiG. 5.-Results of absorption tests on treated and untreated specimens of Mississippi sandstone during an exposure period of 20 months.

siderable water and began to disintegrate during the third winter. However, this should not be considered as an entirely fair test for the material, because the stone to which it was applied was 


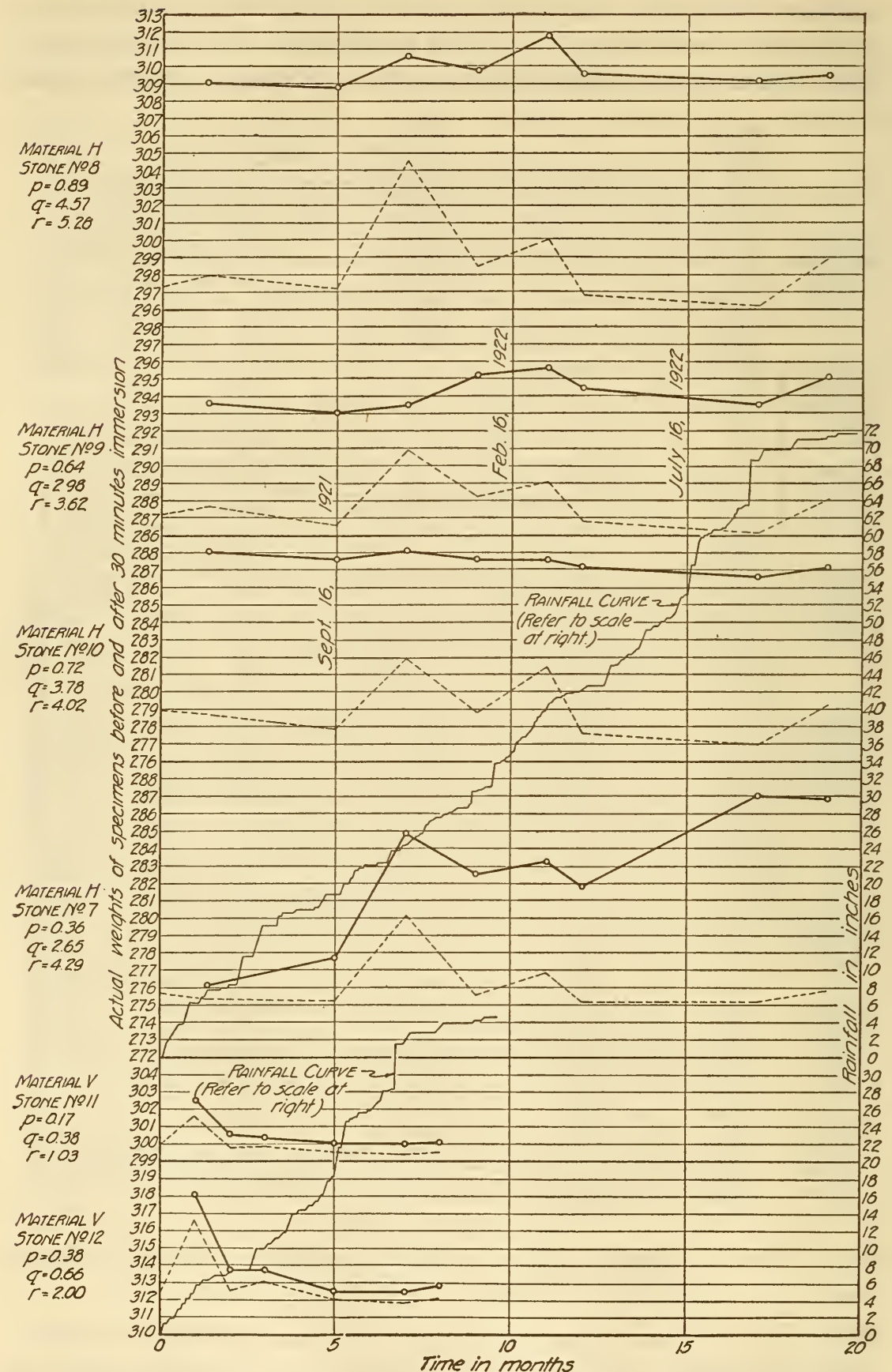

FIG. 6.-Results of absorption tests of two waterproofing materials on Indiana limestone. Exposure periods ranging from 8 to 19 months. 
greatly weakened by previous weathering. In later tests, which are described in another section of this report, the treatment gave excellent results.

None of the materials of Group 3 gave satisfactory results. In Figure 5 materials $\mathrm{P}, \mathrm{Q}$, and $\mathrm{K}$ show very high absorption values during the cold months with a slight decrease during the summer.
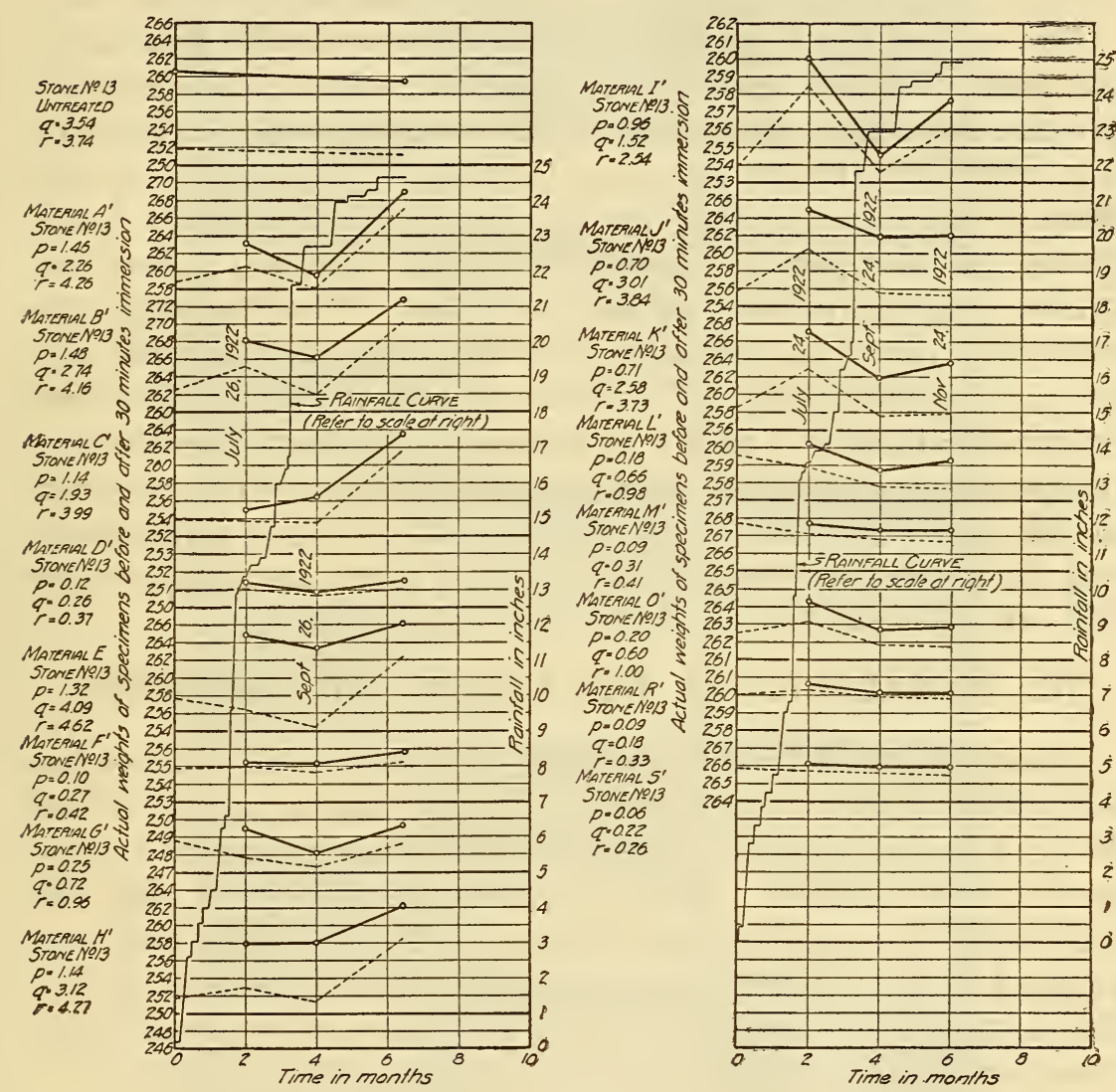

FiG. 7.-Results of absorption tests of I6 waterproofing materials on McDermott, Ohio, sandstone during an exposure period of six months.

The materials of Group 4, which depend on water soluble elements for their waterproofing properties, have shown even less value than those of Group 3. The tests indicate that those which are supposed to react with the stone do so in such a feeble way as to have practically no value in sealing the pores. Those which are intended to act as water repellants have given no great reduction in absorption and have only a temporary value. Two materials in this group have been given considerable attention in these tests, 
due to the fact that they have been marketed to a considerable extent and the producers claim numerous successful cases where they were used. Four series of tests are shown in Figure 6 with material $H$. None of these indicate that the material has any appreciable value after six months exposure to the weather. In Figure 2 a series of tests is shown for material $\mathrm{E}$. This does not indicate even a temporary waterproofing value for the treatment.

One material in Group 5, viz: The molten-paraffin treatment, has been described above. Treatment $T$, which is the nonproprietary process, gave unsatisfactory results in all of the tests. The curves for this are shown in Figure 3. The samples of New Mexico sandstone treated by this process disintegrated badly during the first part of the second winter. Material $\mathrm{J}$ gave less satisfactory results than the last mentioned. The film which the treatment forms on the surface of the stone soon became perforated and later peeled off. The curves for the long-period tests on this treatment are shown in Figure 4. Another series was run on specimens of the same stone with a somwehat thinner solution of the same treatment, with the idea of getting a penetration, but the results were very similar to those given, so the curves for this are not shown.

\section{APPEARANCE OF TREATMENTS ON LIMESTONE.}

The effect of the treatments on the appearance of limestone has been determined by treating one-half of one face of a slab of stone with a waterproofing material, leaving the other half in the natural state for comparisons. Figure 8 shows the slabs soon after the treatments were applied, and Figure 9 after the slabs had been exposed to the weather for 18 months. The right-hand half of the slabs is the treated portion, and the letters in the upper righthand corner refer to the treatments as designated in Section $V$.

It will be noted that all of the treatments discolored the stone at first, some very badly and others much less. Those treatments containing rosin gave the worst appearance and all of the materials in Group I discolored considerably. However, these discolorations are not permanent as will be noted in Figure 9. Practically all of the slabs after I 8 months exposure appear lighter and cleaner on the treated portion than on the untreated portion. This is due partly to the gradual bleaching out of the material applied and partly to the fact that the waterproofing prevents or

reduces the adhesion of dust, soot, etc. The original discolora- 


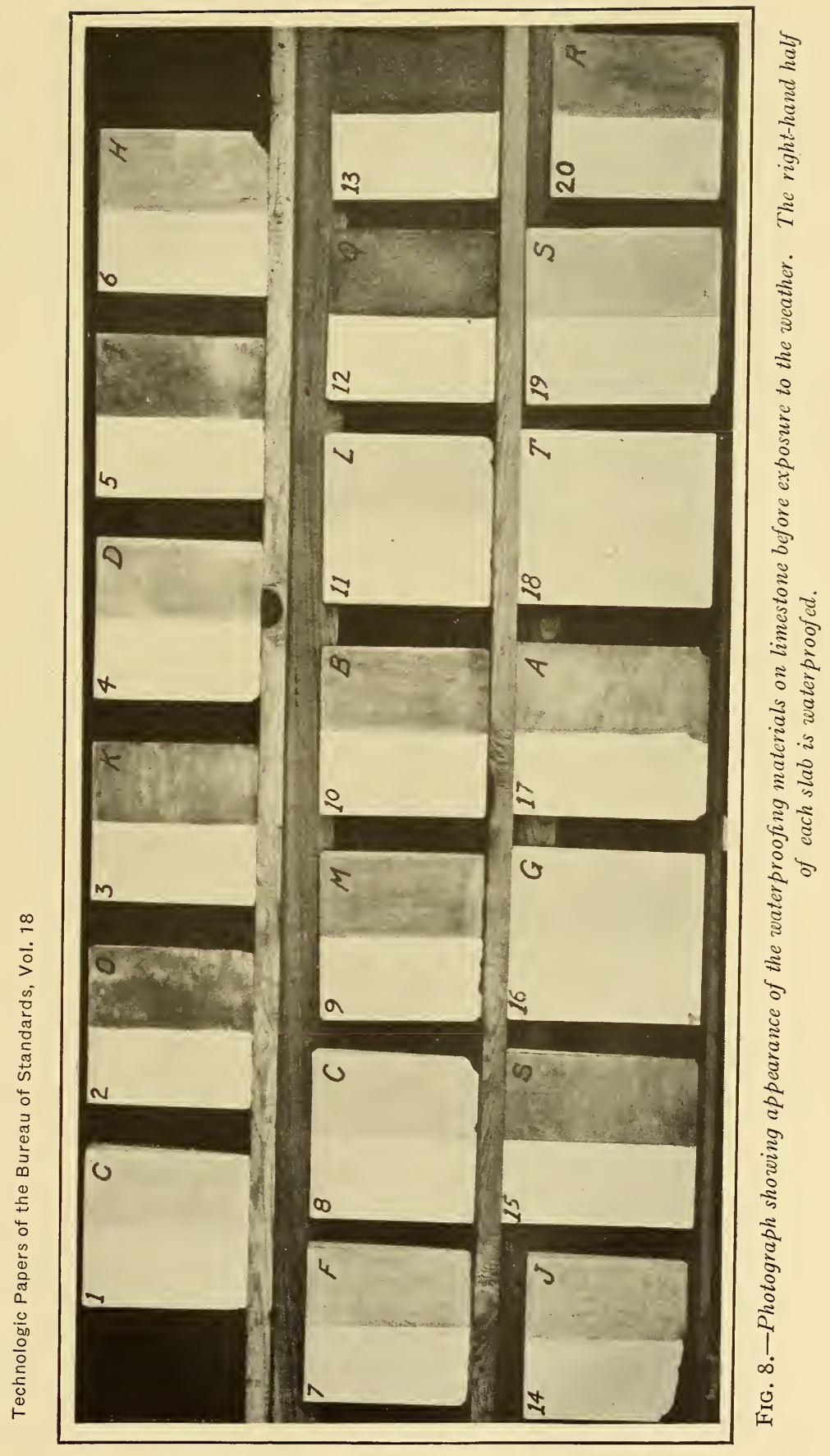




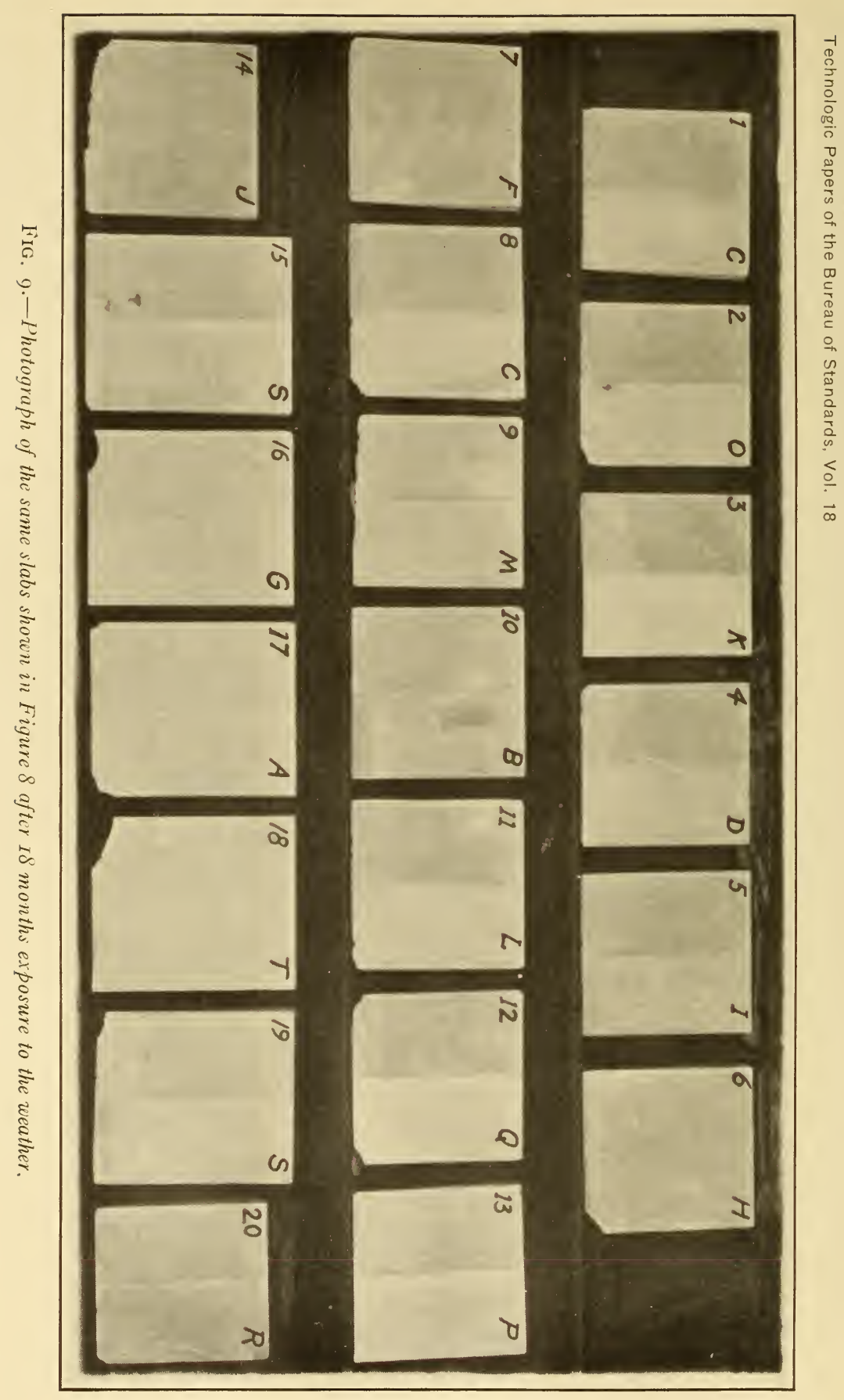


tions were noticeable in most cases for six months or longer after the slabs were exposed to the weather.

Originally it was thought that the depth of penetration of the different materials could be determined by treating a wedgeshaped slab of stone; that is, one which tapers down to a sharp edge. The slabs shown in Figures 8 and 9 were cut in the form of wedges for this purpose, but the treatments did not penetrate through, even at the thin edge. There is good reason to believe that the treatments on the cylindrical specimens used in the absorption tests did penetrate to an appreciable depth. However, no satisfactory reason has been found why they did not penetrate through the thin portions of the wedges. The broken corners of the slabs indicate the thin portions, as they were dressed down so thin that several were broken in handling.

\section{RESULTS OF TESTS ON VARIOUS TEXTURES OF SANDSTONE.}

In order to determine if certain waterproofing materials are more effective on one type of stone than another a rather extensive series of tests was undertaken on three sandstones which gave a considerable range with regard to the closeness of the grains or compactness. The stones used in these tests have been described above, and are referred to as Nos. I3, I4, and I5. Sixteen waterproofing materials were tested on each of the three textures, absorption determinations being made at intervals during a six-month exposure of the samples to the weather. Untreated specimens of the same stones were tested in a similar way as a basis of comparison.

The absorption curves are shown in Figures 7 , IO, and II. For convenience in comparing the results of tests with the various materials on the different stones, the table of " $q$ " values is given below.

TABLE 2.- Values of $q^{1}$ on Sandstones.

\begin{tabular}{|c|c|c|c|c|c|c|c|}
\hline Waterproofing. & $\begin{array}{c}\text { No. } 13 \\
\text { (fine } \\
\text { texture). }\end{array}$ & $\begin{array}{l}\text { No. } 14 \\
\text { (medium } \\
\text { texture). }\end{array}$ & $\begin{array}{c}\text { No. } 15 \\
\text { (coarse } \\
\text { texture). }\end{array}$ & Waterproofing. & $\begin{array}{l}\text { No. } 13 \\
\text { (fine } \\
\text { texture). }\end{array}$ & $\begin{array}{c}\text { No. } 14 \\
\text { (medium } \\
\text { texture). }\end{array}$ & $\begin{array}{c}\text { No. } 15 \\
\text { (coarse } \\
\text { texture). }\end{array}$ \\
\hline 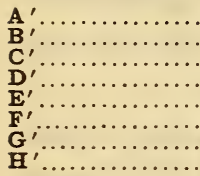 & $\begin{array}{r}2.26 \\
2.74 \\
1.93 \\
.26 \\
4.09 \\
.27 \\
.72 \\
3.12\end{array}$ & $\begin{array}{r}0.45 \\
.15 \\
.30 \\
.99 \\
\ldots \ldots \\
\ldots . .10 \\
3.10 \\
1.39\end{array}$ & $\begin{array}{r}0.44 \\
.11 \\
.40 \\
.17 \\
4.58 \\
.34 \\
4.46 \\
.78\end{array}$ & 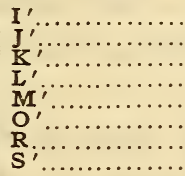 & $\begin{array}{l}1.52 \\
3.01 \\
2.58 \\
.66 \\
.31 \\
.60 \\
.18 \\
.22\end{array}$ & $\begin{array}{r}.22 \\
2.07 \\
4.18 \\
.62 \\
.16 \\
2.75 \\
.04 \\
.10\end{array}$ & $\begin{array}{r}.25 \\
.94 \\
1.94 \\
.35 \\
.44 \\
2.36 \\
.07 \\
.36\end{array}$ \\
\hline
\end{tabular}

${ }^{1} \mathrm{q}=$ average percentage by weight of water contained by the specimens after 30 minutes immersion; that is, it represents the sum of that absorbed from rains and that absorbed while immersed. 
Examination of this table will show that certain materials were effective on the coarse and medium textures, but allowed a considerable absorption when applied to the fine texture.

Materials which showed this to a marked extent are $\mathrm{A}^{\prime}, \mathrm{B}^{\prime}, \mathrm{C}^{\prime}$, and $I^{\prime}$. Those which indicate this to a slight extent are $L^{\prime}$ and
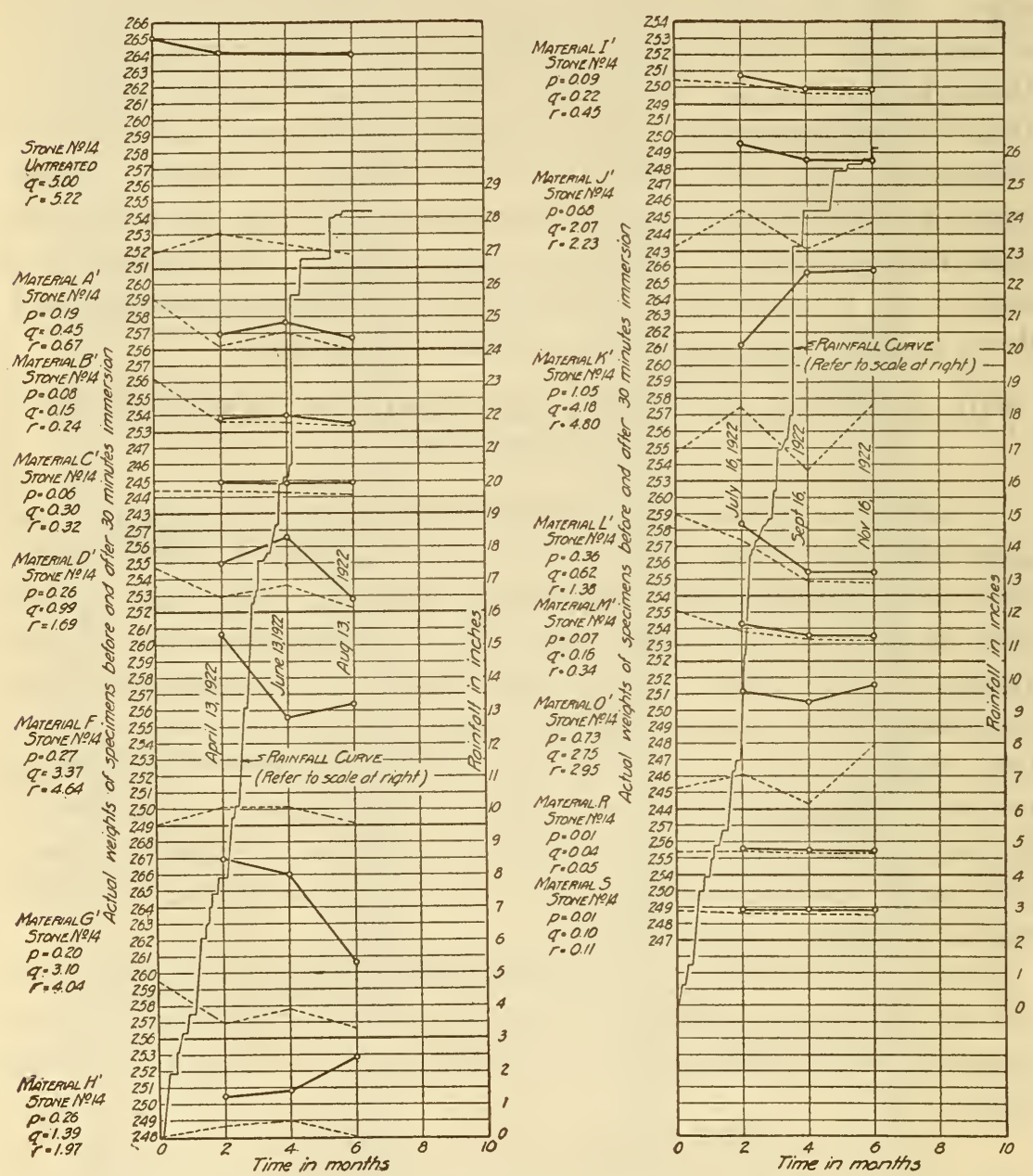

FIG. I0.-Results of absorption tests of I6 waterproofing materials on Amherst, Ohio, sandstone during an exposure period of six months.

$\mathrm{R}^{\prime}$. There are also a few others which gave high absorption values on all of the stones but recorded the highest on the fine texture.

On the other hand, there are two materials in the list which showed the reverse of this, viz: $\mathrm{M}^{\prime}$ and $\mathrm{S}^{\prime}$. However, this is not very pronounced and the values do not show a gradual decline, 
but are lowest on the medium texture. It will also be noted that in the case of those materials which are not adapted to the close texture, a lower absorption is sometimes recorded on the medium texture than on the coarse, or little difference is indicated between the coarse and medium.
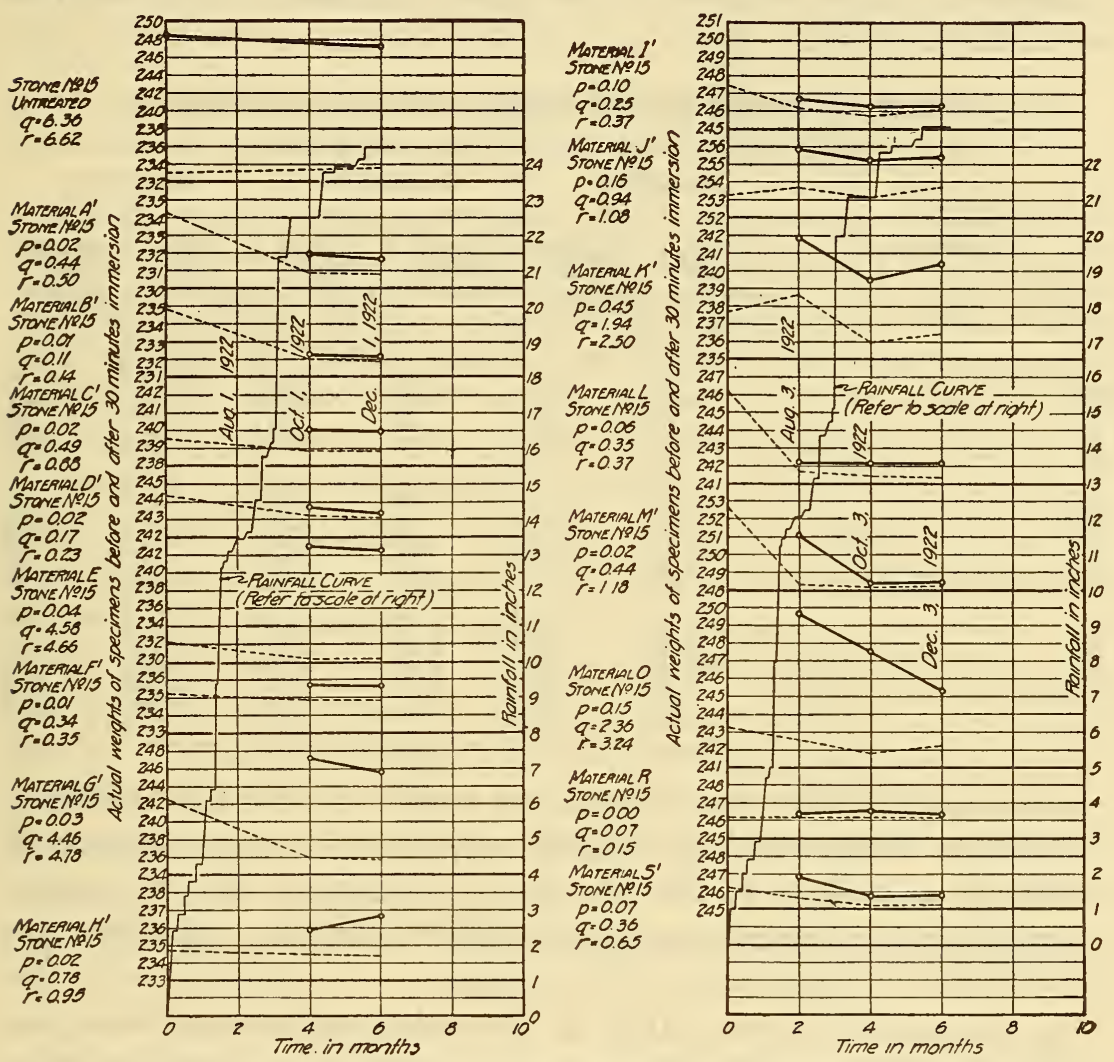

FiG. II.-Results of absorption tests of I6 waterproofing materials on Glenmont, Ohio, sandstone during an exposure period of six months.

The logical conclusion would seem to be that the heavy materials do not penetrate the fine pores. In order to test this theory Table 3 was made up. This gives the average weights of the waterproofing contained in the specimens four days after treatment and four months after treatment. This was obtained by subtracting the actual weights of the specimens before treatment from the dry weights of the treated specimens at the end of the periods mentioned. During the four-day period the specimens were in the laboratory and during the four months they were out in the weather. 
This is only an approximate means of comparing the amounts of waterproofing absorbed by the different stones, because the specimens varied somewhat in size and no compensation for this has been attempted. Furthermore, there may have been slight losses in the specimens due to weathering during the four-month exposure, but the tests on the untreated specimens show that this was inappreciable.

TABLE 3.-Weights of Waterproofing Contained in Sandstones.

\begin{tabular}{|c|c|c|c|c|c|c|}
\hline \multirow[b]{2}{*}{ Material. } & \multicolumn{2}{|c|}{ Stone No. 13.} & \multicolumn{2}{|c|}{ Stone No. 14.} & \multicolumn{2}{|c|}{ Stone No. 15.} \\
\hline & $\begin{array}{l}4 \text { days } \\
\text { after } \\
\text { treatment. }\end{array}$ & $\begin{array}{l}4 \text { months } \\
\text { after } \\
\text { treatment. }\end{array}$ & $\begin{array}{l}4 \text { days } \\
\text { after } \\
\text { treatment. }\end{array}$ & $\begin{array}{l}4 \text { months } \\
\text { after } \\
\text { treatment. }\end{array}$ & $\begin{array}{c}4 \text { days } \\
\text { after } \\
\text { treatment. }\end{array}$ & $\begin{array}{l}4 \text { months } \\
\text { after } \\
\text { treatment. }\end{array}$ \\
\hline 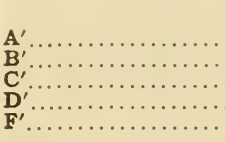 & $\begin{array}{r}\text { g } 1.65 \\
2.07 \\
.94 \\
3.72 \\
.92\end{array}$ & $\begin{array}{r}\text { g } \\
1.00 \\
1.47 \\
.60 \\
3.46 \\
.73\end{array}$ & $\begin{array}{r}\text { g } 5.99 \\
5.71 \\
.36 \\
4.81\end{array}$ & $\begin{array}{r}\mathrm{g} \\
2.83 \\
2.81 \\
.08 \\
2.36\end{array}$ & $\begin{array}{r}\mathrm{g} \\
5.23 \\
5.53 \\
.83 \\
6.50 \\
.71\end{array}$ & $\begin{array}{r}\text { g } \\
1.72 \\
2.63 \\
.08 \\
5.30 \\
.32\end{array}$ \\
\hline $\begin{array}{l}\mathbf{G}^{\prime}, \ldots \ldots \ldots \\
\mathbf{H}^{\prime}, \ldots \ldots \ldots \\
\mathbf{I}^{\prime} \ldots \ldots \ldots \ldots \\
\mathbf{J}_{\mathbf{K}}^{\prime}, \ldots \ldots \ldots \ldots\end{array}$ & $\begin{array}{l}2.63 \\
.78 \\
3.47 \\
1.10 \\
1.89\end{array}$ & $\begin{array}{r}1.13 \\
.59 \\
3.16 \\
.72 \\
1.05\end{array}$ & $\begin{array}{r}5.63 \\
.35 \\
5.50 \\
.26 \\
3.20\end{array}$ & $\begin{array}{r}2.69 \\
.22 \\
4.64 \\
.09 \\
2.13\end{array}$ & $\begin{array}{r}7.40 \\
.64 \\
6.11 \\
.74 \\
3.32\end{array}$ & $\begin{array}{l}1.02 \\
.33 \\
4.78 \\
.63 \\
1.60\end{array}$ \\
\hline 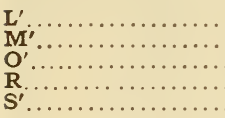 & $\begin{array}{l}2.01 \\
1.22 \\
1.83 \\
2.58 \\
.66\end{array}$ & $\begin{array}{r}.15 \\
.16 \\
.11 \\
2.37 \\
.25\end{array}$ & $\begin{array}{l}5.02 \\
2.87 \\
1.55 \\
6.40 \\
1.49\end{array}$ & $\begin{array}{r}.86 \\
1.12 \\
.66 \\
6.37 \\
1.30\end{array}$ & $\begin{array}{l}5.47 \\
5.62 \\
1.89 \\
8.45 \\
2.70\end{array}$ & $\begin{array}{r}.54 \\
1.15 \\
.46 \\
8.42 \\
1.72\end{array}$ \\
\hline
\end{tabular}

In a general way the table shows that each stone absorbed an amount of solids which is roughly proportional to the amount of solids in solution. It also shows a considerable loss of weight, during the four-month exposure period, which is evidently due to a further evaporation of the solvents.

A comparison of the values in this table and the previous one of $q$ values indicates that the waterproofing values of the materials do not bear any definite relation to the amount of solids in the pores. On the dense stone the best results were obtained with materials $\mathrm{D}^{\prime}, \mathrm{F}^{\prime}, \mathrm{M}^{\prime}, \mathrm{R}$, and $\mathrm{S}^{\prime}$. Two of these showed large amounts of solids in the pores, and two small amounts. On the medium texture the best results were obtained with $\mathrm{B}^{\prime}, \mathrm{C}^{\prime}, \mathrm{I}^{\prime}$, $\mathrm{M}^{\prime}, \mathrm{R}$, and $\mathrm{S}^{\prime}$. Three of these showed large amounts of solids in the pores, and three small amounts. On the coarse texture the best results were obtained with $\mathrm{B}^{\prime}, \mathrm{D}^{\prime}, \mathrm{I}^{\prime}$, and $\mathrm{R}$. All of these showed relatively high amounts of solids in the pores. The highest waterproofing values on all three stones was recorded by treatment $\mathrm{R}$. This treatment gave the highest amount of solids in the pores of the coarse and medium stones, but $\mathrm{D}^{\prime}$ and $\mathrm{I}^{\prime}$ gave 
higher amounts for the dense stone. Here only the weights of waterproofing material contained after four months exposure have been considered, since it is believed that the difference between the weights observed after four days and after four months represented the evaporation of the solvents. It will be noted that in the case of treatment $R$, which consisted of hot paraffin, that there was a very small loss of weight between four days and four months.

\section{APPEARANCE OF THE WATERPROOFING TREAT- MENTS ON THE SANDSTONES.}

On the close-texture sandstone, the natural color of which was bluish gray, none of the treatments could be said to give discolorations which would be especially objectionable after six or eight months of weathering. A number of the treatments appeared dark and oily at first. Treatments $\mathrm{D}^{\prime}, \mathrm{I}^{\prime}$, and $\mathrm{R}$ still showed a slight effect of this nature after six months. Treatment $\mathrm{E}^{\prime}$ showed a slight yellowish brown stain, treatment $\mathrm{J}^{\prime}$ showed shiny patches where the surface film had not peeled off, and $\mathrm{K}^{\prime}$ produced an unsightly coat on the surface resembling lard or tallow, which had mostly scaled off after six months exposure.

The treatments on the medium texture which showed dark oily discolorations after six months exposure were $\mathrm{B}^{\prime}, \mathrm{D}^{\prime}, \mathrm{I}^{\prime}, \mathrm{M}^{\prime}$, and $\mathrm{R}$. These discolorations were considerably worse than those noted on the dense stone, and would probably be considered objectionable in this respect. Treatment $\mathrm{E}$ gave the yellowish brown stain to a marked extent, $\mathrm{J}^{\prime}$ the shiny patches, and $\mathrm{K}^{\prime}$ gave an ugly white coat like tallow, which had only begun to scale at six months.

On the open texture $B^{\prime}, D^{\prime}, I^{\prime}, M^{\prime}, R$, and $S^{\prime}$ gave the oily discolorations, which were even more conspicuous than those on the medium texture. Treatments $\mathrm{J}^{\prime}$ and $\mathrm{K}^{\prime}$ showed the same appearances noted above, but somewhat more pronounced.

The producers of treatment $R$ have a process of removing the excess wax from the surface which serves to clear up the greasy appearance. Several specimens were submitted to this firm for treatment in order to determine to what extent the cleaning process would remove the objectionable discoloration. The results were remarkably good on all the specimens. If the same degree of cleaning is practiced on the actual work it could not be regarded as producing a bad appearance on any of the stones used, viz: Indiana limestone or the three Ohio sandstones described above. 


\section{TESTS FOR RATE OF ABSORPTION ON TREATED SPECIMENS.}

All of the absorption tests discussed in the foregoing section were made for 3o-minute immersion periods. This period was believed, in the beginning, to be about equivalent to the absorp-

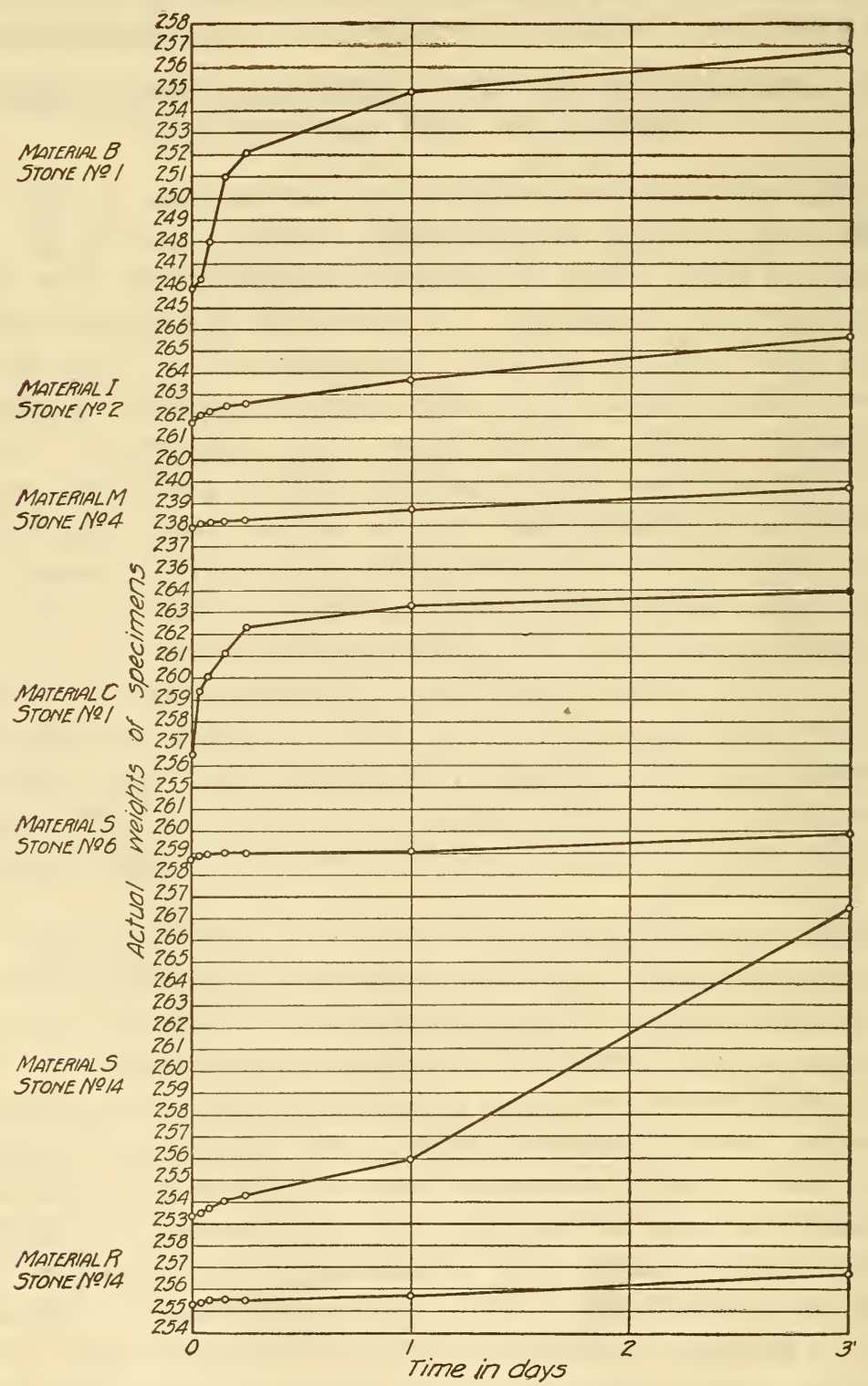

FIG. 12.- Tests for rate of absorption on specimens of limestone and sandstone treated with various waterproofing materials. Tests made after specimens had been exposed to the weather for several months. 
tion of exposed specimens during an ordinary ranstorm. But tests in which the specimens were weighed during or shortly after a large rain indicated that some of the treated specimens absorbed more from the rain than they ordinarily did during 30 minutes immersion. This indicated the desirability of making a few absorption tests over a longer period. Seven of the treatments which gave good values were selected and the specimens treated with these were tested over a three-day immersion period. Weighings were made after I hour, 2 hours, 6 hours, 24 hours, and 3 days to determine the rate of absorption. The results are given in Figure I2, which shows the materials and the stones on which the tests were made. The data for the first five curves were obtained from specimens which had been previously exposed to the weather for approximately two years, and the last two curves from stones which had been exposed for six months.

In these tests material $\mathrm{B}$ allowed a rather rapid absorption during the first six hours and a total for the whole period which was only about I per cent less than the untreated stone. Material $\mathrm{C}$ allowed a more rapid absorption during the first six hours, but the total for the three days was considerably less than that for material B. Materials $\mathrm{M}$ and $\mathrm{S}$ indicated slow rates of absorption and also low absorptions for the whole period. Materials $\mathrm{R}$ and $S$ gave low rates on the medium-texture sandstone during the first few hours. Later $\mathrm{S}$ began to absorb at a higher rate and finally reached a high total, while $\mathrm{R}$ held out very well for the whole period.

\section{TESTS FOR RATE OF DRYING ON TREATED SPECI- MENS.}

It has been suggested that stone treated with a waterproofing material which is only partially effective or one which permits a slow rate of absorption may at times prove injurious by preventing the stone from drying out.

The injurious effect from freezing the stone depends almost entirely on the amount of water contained in the pores. Hence, it seems logical that weather conditions may arise during which the stone will be frozen in a wet condition due to the fact that the waterproofing retarded the drying process.

A few tests were made on some of the treated specimens to determine their effect on the rate of drying. The results of these are shown in Figure 13. The first and fifth curves show the rate of drying for untreated stone, and the others are for specimens 
treated with the materials indicated. The specimens were all soaked in water for three days and then placed on a table in the

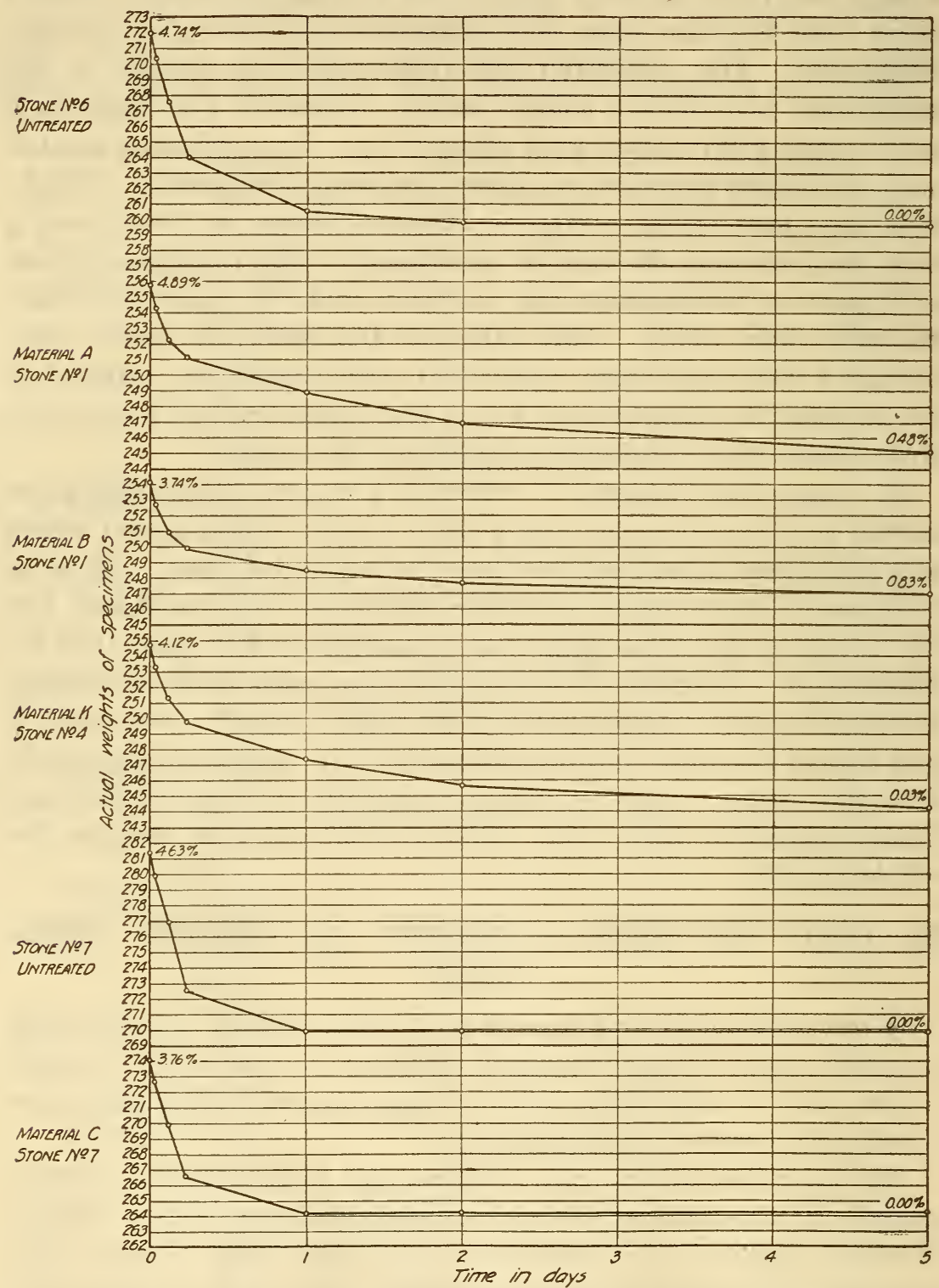

FIG. I3.- Tests for rate of drying on treated and untreated specimens of stone. The percentage figures at the beginning and end of each curve show the amount of water contained at the beginning and end of the tests.

laboratory. They were weighed (at the intervals indicated on the curves by small circles) over a period of five days. 
These curves show that the untreated stone dries almost completely during the first 24 hours. The specimens treated with material A contained nearly half the water after 24 hours. The last curve shows little difference between the treated and untreated specimens, while the other curves indicate an appreciable retardation of the drying process. The percentage values given at the beginning and ending of each curve represents the percentages of water contained by the stone at beginning and ending of the drying process.

\section{CONCLUSIONS.}

The following conclusions are based upon and confined to the materials investigated:

I. The most effective waterproofing materials in this series are those the waterproofing elements of which are heavy petroleum distillates, fatty oils, or insoluble soaps.

2. The effectiveness of any waterproofing may be greatly influenced by the character of the pores in the stone.

3. Stones having close textures are more difficult to waterproof than those with large pores.

4. The treatments giving the highest waterproofing values and appearing to be most durable are those which use paraffin as the waterproofing element, either alone or in conjunction with other materials. The deterioration or loss of waterproofing value on materials of this type is not appreciable within a period of two years.

5. Waterproofing materials employing resinous substances as the waterproofing element are not durable.

6. Materials consisting of aqueous solutions, the purpose of which is to react chemically with the stone or to act merely as water repellants, have only temporary effects.

7. Separate aqueous solutions which react chemically with each other and form insoluble substances in the pores of the stone give low waterproofing values and deteriorate rapidly.

8. In general, those materials which gave the highest waterproofing values produced the greatest discolorations. The amount of this discoloration was proportional to the porosity of the stones. These discolorations decrease on exposure to the weather and after a year or more, depending upon their intensity, they are compensated for by the fact that the treatments tend to prevent the accumulation of dust and soot on the surface of the stone.

WASHINGTON, June I5, 1923. 